\title{
Ediacaran and Cambrian rocks on Scatarie Island and nearby Hay Island, Avalonian Mira terrane, Cape Breton Island, Nova Scotia, Canada
}

\author{
SAndra M. BArR ${ }^{*}$, Chris E. White ${ }^{2}$, Sören Jensen ${ }^{3}$, TeOdoro Palacios $^{3}$, And Deanne van Rooyen ${ }^{4}$ \\ 1. Department of Earth \& Environmental Science, Acadia University, Wolfville, Nova Scotia B4P 2R6, Canada \\ 2. Nova Scotia Department of Energy and Mines, Halifax, Nova Scotia B3J 2T9, Canada \\ 2. Área de Paleontologia, Facultad de Ciencias, Universidad de Extremadura, 06006 Badajoz, Spain \\ 4. Department of Mathematics, Physics, \& Geology, Cape Breton University, Sydney, Nova Scotia B1P 6L2, Canada \\ *Corresponding author: <sandra.barr@acadiau.ca >
}

Date received: 30 July 2020 g Date accepted: 13 September 2020

\begin{abstract}
Scatarie Island and adjacent Hay Island, located $2 \mathrm{~km}$ east of the eastern tip of the Avalonian Mira terrane of southern Cape Breton Island, Nova Scotia, contain a succession of epiclastic and other sedimentary rocks of inferred Ediacaran to Cambrian age. The age assignment was based previously on lithological comparison with the Main-à-Dieu Group and overlying Bengal Road and MacCodrum formations of the Mira River Group. Detrital zircon grains from two sandstone samples from the Bengal Road Formation yielded typical Avalonian detrital zircon spectra with middle to late Neoproterozoic, Meso- to Paleoproterozoic (1300-2200 Ma) and Neoarchean ages. They indicate maximum depositional ages of $532.4 \pm 4.2 \mathrm{Ma}$ and $525.4 \pm 2.4 \mathrm{Ma}$ from essentially the same stratigraphic level, consistent with the interpretation that the rocks are Cambrian. The Bengal Road Formation also yielded scarce organic-walled microfossils including an acanthomorphic acritarch identified as Polygonium sp., also consistent with Cambrian age. The fine-grained siliciclastic succession on Hay Island, tentatively attributed to the MacCodrum Formation, yielded trace fossils, including Teichichnus isp. and Gyrolithes scintillus, that confirm Cambrian age. The Hay Island Gyrolithes scintillus expands the geographical distribution of this ichnospecies, previously known mainly from the Chapel Island Formation of Newfoundland, and represents a younger occurrence.
\end{abstract}

\section{RÉSUMÉ}

L'île Scatarie et l'île Hay voisine, situées à deux kilomètres à l'est de la pointe du terrane avalonien Mira dans le sud de lî̀le du Cap-Breton en Nouvelle-Écosse, abritent une succession de roches épiclastiques et d'autres roches sédimentaires remontant présumément à la période de l'Édiacarien au Cambrien. L'âge attribué était antérieurement basé sur une comparaison lithologique avec le groupe Main-à-Dieu et les formations sus-jacentes de Bengal Road et de MacCodrum du groupe de la rivière Mira. Des grains de zircon détritique provenant de deux échantillons de grès de la Formation de Bengal Road ont affiché des spectres de zircon détritique avaloniens typiques des périodes du Néoprotozoïque moyen à tardif, du Mésoprotozoïque au Paléoprotérozoïque (1300 à $2200 \mathrm{Ma}$ ) et du Néoarchéen. Ils signalent des âges de sédimentation maximaux de 532,4 \pm 4,2 Ma et de 525,4 \pm 2,4 Ma d'un niveau stratigraphique essentiellement identique, ce qui correspond à l'interprétation situant les roches au Cambrien. La Formation de Bengal Road a de plus révélé la présence de microfossiles palynomorphes, notamment un acritarche acanthomorphe identifié en tant que l'espèce Polygonium, ce qui correspond également à l'époque du Cambrien. La succession silococlastique à grains fins sur l'île Hay, rattachée à la Formation de MacCodrum, a présenté des ichnofossiles, par exemple, l'ichnoespèce Teichichnus et le Gyrolithes scintillus, qui confirment l'âge du Cambrien. Le Gyrolithes scintillus de l'île Hay élargit la distribution géographique de cette ichnoespèce, antérieurement reconnue comme une espèce principalement présente dans la Formation de Chapel Island de Terre-Neuve, et il représente une occurrence plus récente.

[Traduit par la redaction] 
INTRODUCTION

Scatarie Island is a Nova Scotia Wilderness Protected area (https://novascotia.ca/nse/protectedareas/wa_scatarie.asp) located in the Cabot Strait $2 \mathrm{~km}$ from the southeastern tip of Cape Breton Island (Fig. 1). The island has a long history as a fishing settlement, and archaeological research has provided evidence for 18th century fishing activity on the island; tales abound of life there in the Nineteenth and Twentieth centuries. The area is also known for its long history of shipwrecks, most recently the Great Lakes freighter M.V. Miner, which ran aground when a towing cable broke in September 2011 and which was removed from the island in 2015 (https://novascotia.ca/news/release/?id=20150622003).

Although designated a protected area because of its rare or unusual flora, the bedrock geology on Scatarie Island is also remarkable because it includes a rare occurrence of rocks that formed during a time interval that spans the boundary between the Ediacaran and Cambrian periods of geological time (Barr et al. 1992, 1996). Although much of the interior of the island consists of dense spruce and fir forest, barrens, and bogs and hence lacks outcrop, the Ediacaran-Cambrian rocks are well exposed along parts of the shoreline. The purpose of this paper is to present the first direct paleontologi$\mathrm{cal}$ and $\mathrm{U}-\mathrm{Pb}$ zircon evidence that rocks formed during the Ediacaran/Cambrian transition are exposed on the eastern part of Scatarie Island and adjacent Hay Island (Fig. 2).
REGIONAL BACKGROUND

Southeastern Cape Breton Island, geologically comprising the Mira terrane (Barr and Raeside 1989), is part of Avalonia in the northern Appalachian orogen (Fig. 1, inset). Like other parts of Avalonia, the Mira terrane is characterized by Neoproterozoic volcanic, sedimentary, and plutonic rocks, overlain by lower Paleozoic sedimentary rocks (Fig. 1). Weeks (1954) included all the Precambrian volcanic and sedimentary rocks in a single unit called the Fourchu Group; but based on mapping, petrological studies, and $\mathrm{U}-\mathrm{Pb}$ zircon dating, Barr et al. $(1992,1996)$ subdivided the rocks into groups of three different ages, ca. $680 \mathrm{Ma}$, ca. $620 \mathrm{Ma}$, and ca. $575 \mathrm{Ma}$ (Fig. 1). The name Fourchu Group was retained only for the ca. $575 \mathrm{Ma}$ volcanic and minor sedimentary rocks in the coastal part of the terrane south of Louisbourg. The new name Main-à-Dieu Group was assigned to rocks west, north, and east of Louisbourg that were considered equivalent in age to and/or younger than the Fourchu Group on the basis of field relations, petrological characteristics, and a poorly constrained $\mathrm{U}-\mathrm{Pb}$ zircon age of $<560 \mathrm{Ma}$ from a rhyolite sample (Bevier et al. 1993). Other group names were assigned to volcanic, volcaniclastic, and sedimentary rocks farther south and west in the terrane, based mainly on $\mathrm{U}-\mathrm{Pb}$ zircon ages from volcanic rocks and associated plutons (Fig. 1). Subsequently, formation names were introduced for lithological units within each of these groups by Barr and White (2017a, b).

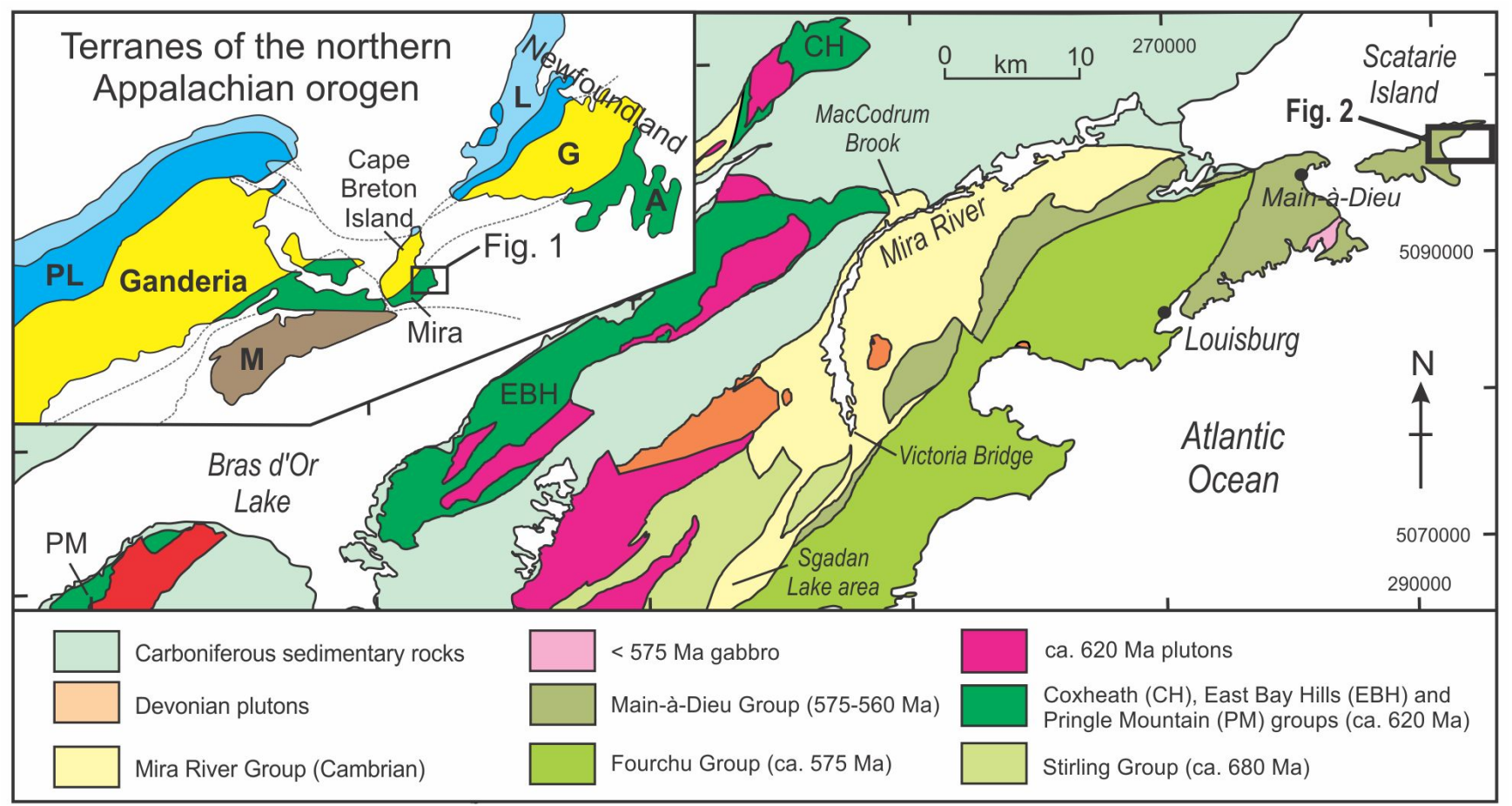

Figure 1. Simplified geological map of the northern part of the Mira terrane, southeastern Cape Breton Island, modified from Barr et al. (1996), showing the distribution of Neoproterozoic, Cambrian, and Carboniferous rocks and the location of Scatarie Island. Inset map shows the location of the Mira terrane and map area in the context of northern Appalachian terranes, modified from Hibbard et al. (2006). $\mathrm{A}=$ Avalonia, $\mathrm{G}=$ Ganderia, $\mathrm{L}=$ Laurentian margin, $\mathrm{M}=\mathrm{Meguma}, \mathrm{PL}=$ peri-Laurentian arcs. 


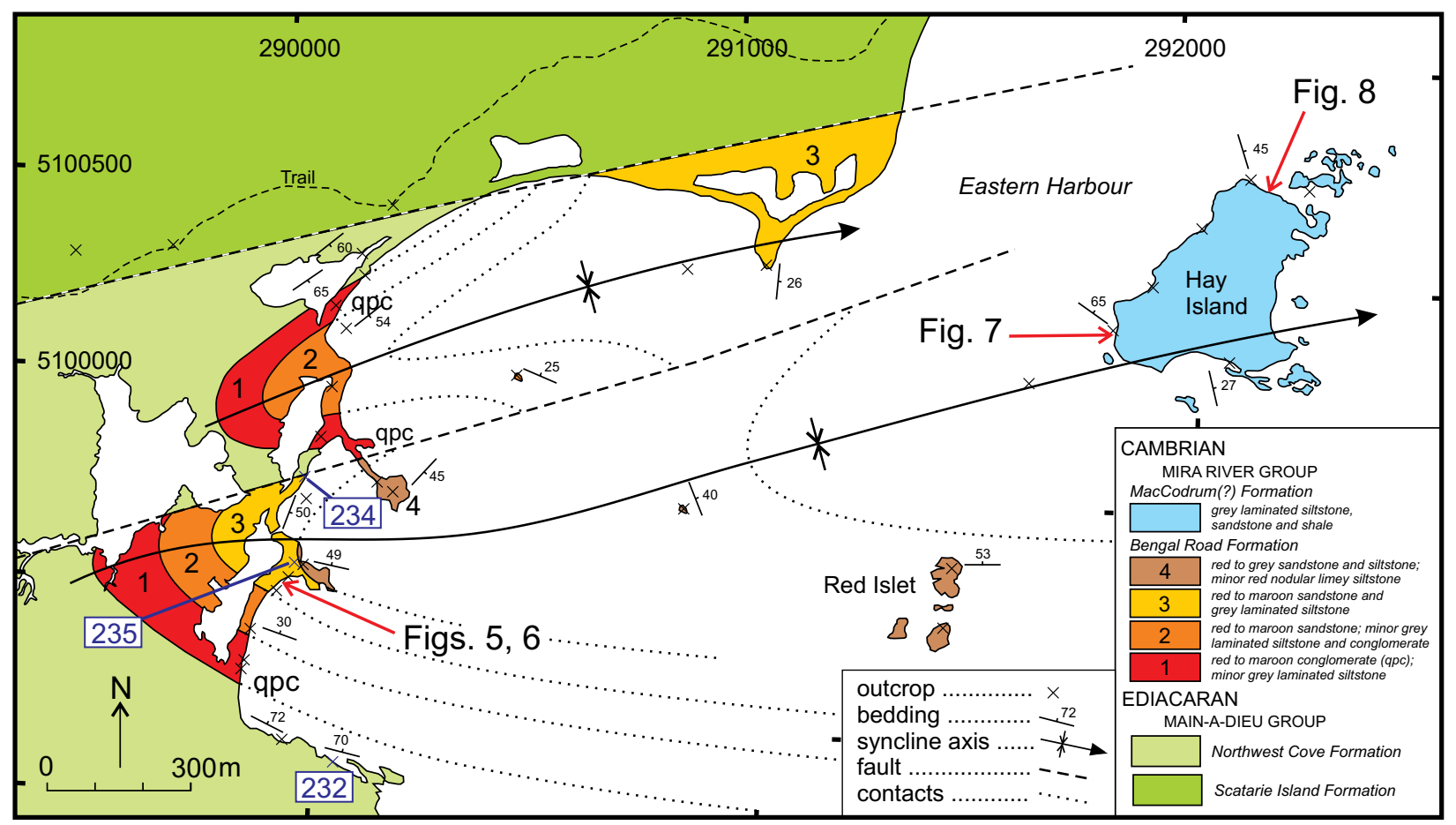

Figure 2. Geological map of the southeastern part of Scatarie Island and nearby Hay Island modified from Barr and White (2017a, b, c). Locations of dated samples SMB17-234 and 235 are shown in member 3 of the Bengal Road Formation, as well as sample SMB17-232 from the underlying Northwest Cove Formation which lacked zircon. Also shown are locations of photographed specimens in Figs. 6-8. Location for sample SMB17-232 = Grid Zone 21T (WGS84) 2899985099504

The Cambrian sedimentary rocks that locally overlie the Neoproterozoic volcanic, sedimentary, and plutonic rocks form a broadly synclinal structure in the Mira River area, and Barr and White (2017a, b) referred to them collectively as the Mira River Group. Hutchinson (1952) and Weeks (1954) divided Cambrian sedimentary rocks into six formations: Morrison River, MacCodrum, Canoe Brook, Trout Brook, MacLean, and McNeil. Barr et al. $(1992,1996)$ retained these formation names except for Morrison River, which they replaced by the Bengal Road and Sgadan Lake formations because they considered the latter to be mappable units distinct from the red beds in the underlying Mainà-Dieu Group, all of which had been included previously in the Morrison River Formation (Weeks 1954).

As defined by Barr et al. (1992, 1996), the Bengal Road Formation is a dominantly red clastic sedimentary unit that overlies volcanic and sedimentary rocks of the Main-à-Dieu Group. Contacts are mainly faults or are unexposed, but an originally disconformable relationship is most likely. The Bengal Road Formation differs from sedimentary units of the underlying Main-à-Dieu Group in that the former contains abundant detrital muscovite and lacks volcanic and volcaniclastic rocks. It also contains a distinctive quartzitequartz-pebble conglomerate unit at or near its base, and is interlayered with, and overlain by, red sandstone and siltstone, commonly with well-developed cross-bedding and graded bedding. Landing (1991) correlated this red bed unit of the Mira terrane with the late Ediacaran Rencontre For- mation of Newfoundland; but Barr et al. (1992, 2003, 2012) and Reynolds et al. (2009) considered it to be Cambrian based mainly on the presence of detrital muscovite and on other lithological contrasts with underlying non-micaceous red beds. Maximum depositional ages of ca. 544 and $537 \mathrm{Ma}$ were reported by Willner et al. (2013) based on U-Pb dating of detrital zircon from the Mira River area.

The overlying Sgadan Lake Formation is a distinctive white, rarely maroon, cross-bedded quartz arenite which is locally conglomeratic with abundant quartz pebbles. The Sgadan Lake Formation in its type area near Sgadan Lake was correlated with the Random Formation of Newfoundland by Landing (1991). Landing (1991) also recognized a separate unit of shale between the red bed and quartz arenite units that he correlated with the Chapel Island Formation, which in Newfoundland occurs between the Rencontre and Random formations. Barr et al. (1996) also noted the presence of shale and siltstone but did not consider those rocks to constitute a separate mappable unit and so included them in their Bengal Road Formation. Barr et al. (2012) reported a single concordant detrital zircon age of ca. $529 \mathrm{Ma}$ from the Sgadan Lake Formation in its type area, although a single analysis cannot be considered to provide a reliable maximum depositional age.

Barr et al. $(1992,1996)$ also assigned white quartz arenite and conglomerate in MacCodrum Brook to their Sgadan Lake Formation, although Landing (1991) had placed those rocks in the Rencontre Formation. The Sgadan Lake Formation 
in MacCodrum Brook is overlain by the type section of the MacCodrum Formation of Hutchinson (1952). It consists of grey and green siltstone and shale, with minor sandstone intervals. Carbonate nodules are present close to the base of the formation and also higher in the section. This section is the only good exposure of this unit, because many outcrops farther south in the Mira River area originally attributed to the MacCodrum Formation by Hutchinson (1952) were later shown to belong to younger units (Landing 1991; Barr et al. 1996). By comparison with Newfoundland, Landing (1991) equated the type section of the MacCodrum Formation with the Bonavista Group (Cambrian Stage 2-3) and suggested that an unconformity is present between it and the underlying quartz arenite. However, Barr et al. (1996) observed interlayered quartz arenite and shale in some locations and hence, like Hutchinson (1952), considered that the units are conformable. Later Landing (2004) revised his earlier correlation of the type section of the MacCodrum Formation with Newfoundland units because of the higher sandstone content than found in the Bonavista Group, and instead attributed it to the Chapel Island Formation. The details of rocks in the MacCodrum Brook section are further complicated by the fact that Willner et al. (2013) reported a maximum depositional age of $517 \pm 3 \mathrm{Ma}$ for the Sgadan Lake quartz arenite there, based on results from an eightgrain detrital zircon population. Results of work in progress to evaluate the implications of this young age and the details in the still-enigmatic MacCodrum Brook section will be reported in a subsequent paper.

The MacCodrum Formation is the oldest unit on Cape Breton Island that has yielded trace fossils (Landing 2004) and acritarchs (Palacios et al. 2015). Acritarchs from the type section on MacCodrum Brook include Granomarginata and Asteridium (Palacios et al. 2015). Acritarchs and trace fossils from the type section are consistent with attribution to the Fortunian or Cambrian Stage 2. The overlying Canoe Brook Formation consists of red-brown, carbonate-rich mudstone and siltstone, maroon siltstone containing grey-green reduction spots, and minor pink to red limestone. According to Landing (1991), the Canoe Brook Formation, as well as the upper part of the underlying MacCodrum Formation (as originally mapped by Hutchinson 1952), are equivalent to the Bonavista Group and Brigus Formation in Newfoundland based on lithological characteristics and skeletal fossils. The contact between the MacCodrum and Canoe Brook formations is nowhere exposed. Landing (1991) recovered skeletal fossils from the Canoe Brook Formation along the Louisbourg Highway, which he attributed to the Camenella baltica Zone of Cambrian Stage 3 (Geyer 2019). From the upper part of the formation, Landing (1991) reported the trace fossil Teichichnus and trilobite hash. Trilobites were also discovered by Hutchinson (1952), who reported the Cambrian Stage 3 Callavia Zone-trilobite Strenuella strenua from the Victoria Bridge area (Fig. 1) in rocks originally attributed to the MacCodrum Formation but now part of the Canoe Brook Formation (Barr et al. 1996).

The Trout Brook Formation (Hutchinson 1952), dom- inantly dark-grey to rust-brown, well cleaved shale and siltstone, overlies the Canoe Brook Formation. Toward the stratigraphic top of the Trout Brook Formation, the shale becomes locally maroon, with thin, graded beds of finegrained sandstone. The Trout Brook Formation contains Miaolingian trilobites (Hutchinson 1952) and acritarchs (Palacios et al. 2009). The MacLean Brook Formation (Hutchinson 1952) overlies the Trout Brook Formation, and consists of interbedded grey quartz sandstone, siltstone, and shale with minor light-grey quartz sandstone and maroon shale. It contains Miaolingian trilobites (Hutchinson 1952) and Miaolingian and Furongian acritarchs (Palacios et al. 2009). The MacLean Brook Formation appears to be conformable with the underlying shales of the Trout Brook Formation and is overlain by grey shale, siltstone, and limestone of the Furongian McNeil Formation (Hutchinson 1952).

\section{GEOLOGY OF SCATARIE ISLAND AND HAY ISLAND}

The geology of Scatarie Island was first described by Fletcher (1879), who provided a vivid description of the island and recognized various types of "felsites" from coastal sections. He also reported a conglomerate visible at low tide on eastern Scatarie Island that he thought to be of probable Carboniferous age, subsequently assigned to the Cambrian Bengal Road Formation (Barr et al. 1996, 2003, this paper). Weeks (1954) included all of Scatarie Island in his Fourchu Group, based on mapping by Hayes et al. (1938). However, Barr and White (1989) and Barr et al. (1996) re-assigned most of the Scatarie Island rocks to the Main-à-Dieu Group and also recognized for the first time the presence of probable Cambrian rocks overlying the Main-à-Dieu Group on the eastern part of the island (Fig. 2).

Barr et al. (1996) divided the Main-à-Dieu Group on Scatarie Island into map units based on rock type, and those units were assigned formation names by Barr and White (2017a, b, c). The inferred oldest unit on the island, the Scatarie Island Formation, forms the northeastern part of the island, in faulted contact to the south with the Northwest Cove Formation and Cambrian rocks of the Bengal Cove Formation (Fig. 2). The Northwest Cove Formation is the uppermost formation in a conformable stratigraphic succession that youngs consistently to the east across Scatarie Island (Barr et al. 1996; Barr and White 2017c). The formation consists mainly of amygdaloidal basaltic flows interlayered with red volcanogenic conglomerate, epiclastic sandstone, and tuff.

The overlying mainly red to maroon sedimentary rocks were assigned to the Cambrian Bengal Road Formation based on lithology (Barr et al. 1992, 1996). The distribution of rock types, structural orientations, and well-preserved younging directions indicate that the Bengal Road Formation occurs in a faulted synclinal structure (Fig. 2). At the time of a visit in August 1991, a gap of about $10 \mathrm{~m}$ separated the uppermost amygdaloidal basalt flow of the Northwest 
Cove Formation from an outcrop of quartzite- and quartz-pebble conglomerate, characteristic of the base of the Bengal Road Formation elsewhere in the Mira terrane (Barr et al. 1992). The conglomerate is repeated in three outcrops in the well-exposed section, although during our most recent visit in 2017, the southernmost outcrops observed in 1991 were not exposed. The rocks are divided into four members. The quartzite- and quartz-pebble conglomerate (member 1) grades into red to maroon sandstone with minor interbedded grey laminated siltstone and conglomerate of member 2 , and then into a unit of red to maroon sandstone and grey laminated siltstone which lacks conglomerate (member 3), overlain by red to grey sandstone and siltstone with minor red nodular limey siltstone (member 4). Younging direction is clear throughout this section, and the first three members are repeated north of an east-northeast-trending fault (Fig. 2). All four members contain abundant detrital muscovite, absent from the underlying Northwest Cove Formation and other formations of the Main-à-Dieu Group.

Some control from mainly submerged rocky shoals enables the synclinal structure to be traced offshore toward Hay Island, but red beds do not occur on the island. There, the rocks are grey laminated siltstone, sandstone, and shale that appear lithologically similar to the MacCodrum Formation in the Mira River area (Barr et al. 1992, 1996). However, based on some lithological similarities to the Trout Brook Formation, in their more recent compilation maps Barr and White $(2017 \mathrm{c})$ assigned the Hay Island rocks to the Trout Brook Formation. In either case, no evidence for the white quartz arenite of the Sgadan Lake Formation, or for other intervening formations, was observed, and if present, it is hidden under water.

\section{U-PB GEOCHRONOLOGY}

\section{Sample descriptions and methods}

Three samples (SMB17-232, 234, and 235) were collected for $\mathrm{U}-\mathrm{Pb}$ dating of detrital zircon but only the latter two contained zircon grains. Sample SMB17-232 is red pebble conglomerate from the upper part of the Northwest Cove Formation (Fig. 2). The conglomerate overlies and underlies amygdaloidal basalt flows. It contains abundant plagioclase and epidote clasts and varied lithic fragments (including volcanic glass, basalt, dacite, and rhyolite) but minor quartz and no detrital muscovite or zircon.

In contrast, samples SMB17-234 and 235, both from the red to maroon sandstone and grey laminated siltstone of member 3, contain abundant detrital muscovite, as well as zircon. SMB17-234 is red arkosic sandstone with abundant angular quartz and less abundant plagioclase clasts. Lithic clasts include both volcanic and clastic sedimentary material. Sample SMB17-235 is greywacke, finer grained than sample 234 and with more abundant muscovite. Many of the muscovite fragments had been deformed and crenulated prior to deposition. They occur with quartz and feldspar clasts in a muddy matrix that forms about $25 \%$ of the rock.

The samples were sent to Overburden Drilling Management (Ottawa, Ontario) for electro-pulse disaggregation and zircon separation. Zircon grains in samples SMB17-234 and 235 were then handpicked, mounted on an epoxy- covered thin section, polished to expose the centres of the zircon grains, and imaged using cold cathodoluminescence to identify internal zoning and inclusions. These images were used to select ablation points $(30 \mu \mathrm{m}$ diameter), avoiding any visible inclusions, cracks, or other imperfections. Grains were analyzed by laser ablation inductively coupled plasma mass spectrometry (LA-ICPMS) at the Department of Earth Sciences, University of New Brunswick (Appendix A: Table A1 and A2 - two runs for each sample are reported and all data from both runs are analyzed and discussed together). $\mathrm{U}$ and $\mathrm{Pb}$ isotopic compositions were measured using a Resonetics S-155-LR $193 \mathrm{~nm}$ Excimer laser ablation system connected to an Agilent $7700 \times$ quadrupole in-ductively coupled plasmamass spectrometer, following the procedure outlined by McFarlane and Luo (2012) and Archibald et al. (2013). Data reduction was done in-house using Iolite software (Paton et al. 2011) to process the laser output into data files, and further reduced for $\mathrm{U}-\mathrm{Pb}$ geochronology using VizualAge (Petrus and Kamber 2012).

Corrections are applied as follows: for grains with $<100$ counts $/ \mathrm{s}{ }^{204} \mathrm{~Pb}$, data are uncorrected; for grains where the percentage error on the ${ }^{204} \mathrm{~Pb}$ counts per second was $<20 \%$, we used a ${ }^{204} \mathrm{~Pb}$-based correction (Andersen 2002), and for grains where the percentage of radiogenic $\mathrm{Pb}\left(\mathrm{Pb}^{*}\right.$ in file) is less than $98.5 \%$ we used a ${ }^{208} \mathrm{~Pb}$-based correction (Petrus and Kamber 2012). Data were sorted by \% concordance $\left({ }^{206} \mathrm{~Pb} /{ }^{238} \mathrm{U}\right.$ versus ${ }^{207} \mathrm{~Pb} /{ }^{235} \mathrm{U}$ for grains $<1000 \mathrm{Ma}$ and ${ }^{206} \mathrm{~Pb} /{ }^{238} \mathrm{U}$ versus ${ }^{207} \mathrm{~Pb} /{ }^{206} \mathrm{~Pb}$ for grains $>1000 \mathrm{Ma}$ ), and by the $\%$ of radiogenic $\mathrm{Pb}$ in the grains as calculated using VizualAge (Appendix A: Tables A1 and A2). Concordia and weighted mean ages as well as probability distribution histograms were calculated using Isoplot version 4.15 (Ludwig 2012).

Probability distribution histograms are based on ${ }^{206} \mathrm{~Pb} /{ }^{238} \mathrm{U}$ dates for grains $<1000 \mathrm{Ma}$ and ${ }^{207} \mathrm{~Pb} /{ }^{206} \mathrm{~Pb}$ dates for $>1000 \mathrm{Ma}$ and show all grains that are between 90 and $102 \%$ concordant. To determine the youngest age represented in each sample we used only clusters of more than 3 grains with ages that overlap within error and are $98-101 \%$ concordant. Using only near-concordant grains that overlap within error is a conservative approach, which serves to reduce the possibility of misrepresenting the maximum depositional age as too young by using single grains that may have experienced $\mathrm{Pb}$ loss (Dickinson and Gehrels 2010). Data for reference materials FC-1 and Plesovice are presented in Appendix A, Table A2, with standards for Run 1 and Run 2 shown separately.

\section{Results}

Sample SMB17-234 contains zircon grains with a wide range of sizes between $50-300 \mu \mathrm{m}$, and grains of all sizes 
were analyzed. Some of the larger grains are subhedral and rectangular and some are rounded and anhedral; the smaller grains are mostly subhedral to anhedral and rounded. All analyzed grains had very weak fluorescence in CL but some of the larger grains showed faint oscillatory zoning. Of 132 grains analyzed, 80 are between 90 and $102 \%$ concordant (Appendix A: Table A1). The major peak in the cumulative probability distribution is around 520-530 Ma, with minor peaks at $1.5 \mathrm{Ga}, 1.8 \mathrm{Ga}$ and $2.0 \mathrm{Ga}$ and a few grains at $3.0 \mathrm{Ga}$ (Figs. 3a, b). The gaps in ages at around $1000 \mathrm{Ma}$ and around $2500 \mathrm{Ma}$ are typical of detrital zircon signatures in Avalonia, as is the scatter of ages between about 1300 and $2100 \mathrm{Ma}$ (e.g., Barr et al. 2012). Among the Neoproterozoic to Cambrian grains, it is possible to calculate a concordia age for 12 grains in the youngest peak at $526.3 \pm 2.2 \mathrm{Ma}$, but the mean square of weighted deviation (MSWD) is very high at 7.0 and has a correspondingly low probability of concordance at 0.008 (Fig. 3c). The weighted mean age for the same 12 grains is $525.4 \pm 2.4 \mathrm{Ma}$ with a much lower MSWD of 1.11 (Fig. 3d). In this case the weighted mean age at $\sim 525 \mathrm{Ma}$ is likely the most robust estimate of the maximum depositional age for this sample.

Zircon grains in sample SMB17-235 range in size from $50-200 \mu \mathrm{m}$ and grains of all sizes were analyzed. Some of the larger grains are subhedral and acicular to rectangular whereas the smaller grains are mostly subhedral to anhedral and rounded. All of the grains had weak fluorescence in CL but some of the larger grains showed faint oscillatory zoning. Of 128 grains analyzed, 86 are between 90 and 102\% concordant (Appendix A: Table A1). The major peak in the cumulative probability distribution is around $530 \mathrm{Ma}$, with minor peaks at $1.5 \mathrm{Ga}, 1.8 \mathrm{Ga}$ and $2.0 \mathrm{Ga}$ and a few grains around $2.7 \mathrm{Ga}$ and $3.4 \mathrm{Ga}$ (Figs. 4a, b). Like sample SMB17234, this sample also displays the gaps at ca. 1000 and 2500 $\mathrm{Ma}$ and a spread of ages between about 1300 and $2200 \mathrm{Ma}$, typical of Avalonia. For Neoproterozoic to Cambrian grains,
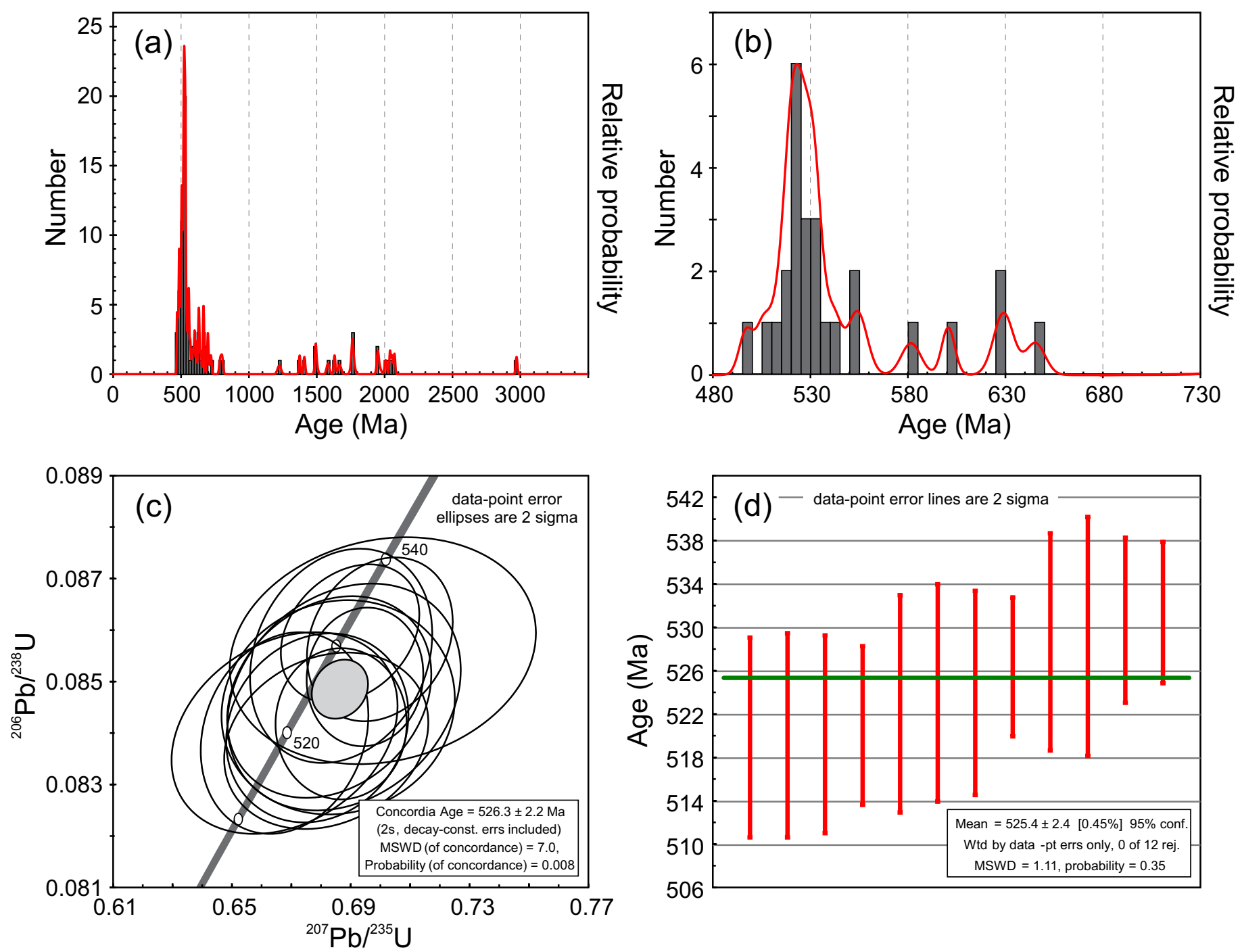

Figure 3. U-Pb zircon diagrams for sample SMB17-234 (data from Table A1). (a) Probability plot for all data between 90 and $102 \%$ concordant. (b) Expanded view of probability plot in (a) for ages less than $750 \mathrm{Ma}$. (c) Concordia diagram for youngest statistically valid age population. (d) Weighted mean diagram for the same 12 grains shown in (c). 
three separate peaks occur on the cumulative probability distribution (Fig. 4b), but the calculated concordia age for the youngest group of 5 grains is $534.4 \pm 3.9 \mathrm{Ma}$ with a high MSWD of 4.5 and a low probability of concordance at 0.034 . The weighted mean age of the same 5 grains is $532.4 \pm 4.2$ Ma with a much lower MSWD of 0.15 (Fig. 4d). In this case the weighted mean age is likely the most robust estimate of the maximum depositional age for this sample. The grains with ages scattered between $550 \mathrm{Ma}$ and $780 \mathrm{Ma}$ could all have sources within Avalonia (e.g., van Staal et al. 2020).

\section{TRACE FOSSILS AND ORGANIC-WALLED MICROFOSSILS}

\section{Material and methods}

Coastal sections on eastern Scatarie Island and on Hay
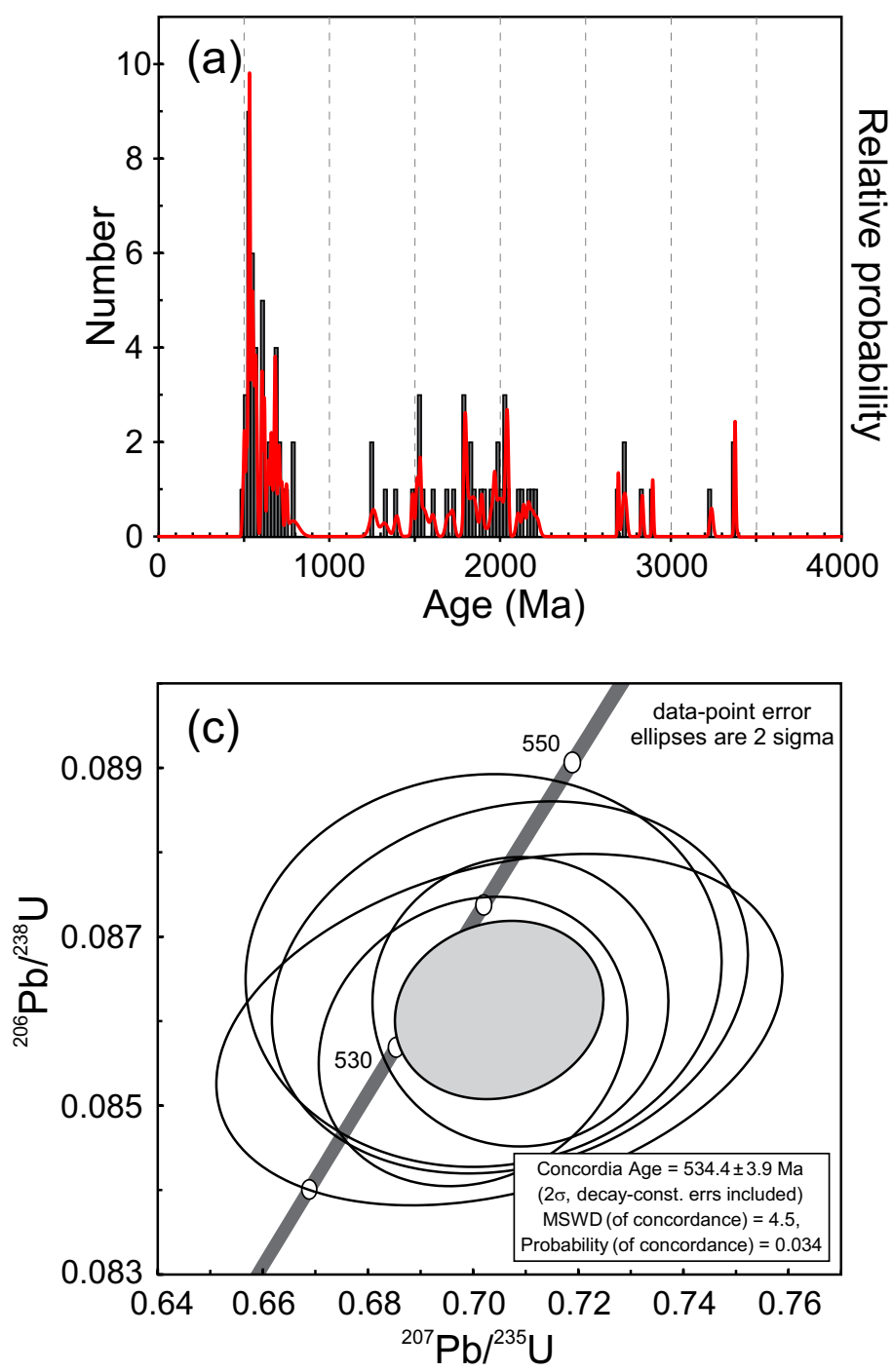

Island were examined for their fossil contents and documented by digital photography. More than $100 \mathrm{~m}$ of continuous outcrop of the Bengal Road Formation is accessible at low tide. As exposed in July 2017, the section commenced with about $30 \mathrm{~m}$ of laminated and thin-bedded, yellow- and brown-weathering grey siltstone and minor sandstone of member 2. Small-scale truncations and bedding rupture is commonly seen (Figs. $5 \mathrm{a}-\mathrm{c}$ ). The proportion of sandstone increases up-section into member 3 and include beds with large cubes of pyrite (Fig. 5d). Three samples of darkgrey silt-stone were collected for organic-walled microfossils from this section. Member 3 is overlain by red sandstone/siltstone of member 4 (Fig. 5e) which contains minor red nodular limey siltstone (Fig. 5f).

Outcrops tentatively attributed to the MacCodrum Formation were examined at three coastal sections on Hay Island, with a total of five samples collected for organic-walled microfossils (Fig. 2). Samples collected for organic-walled
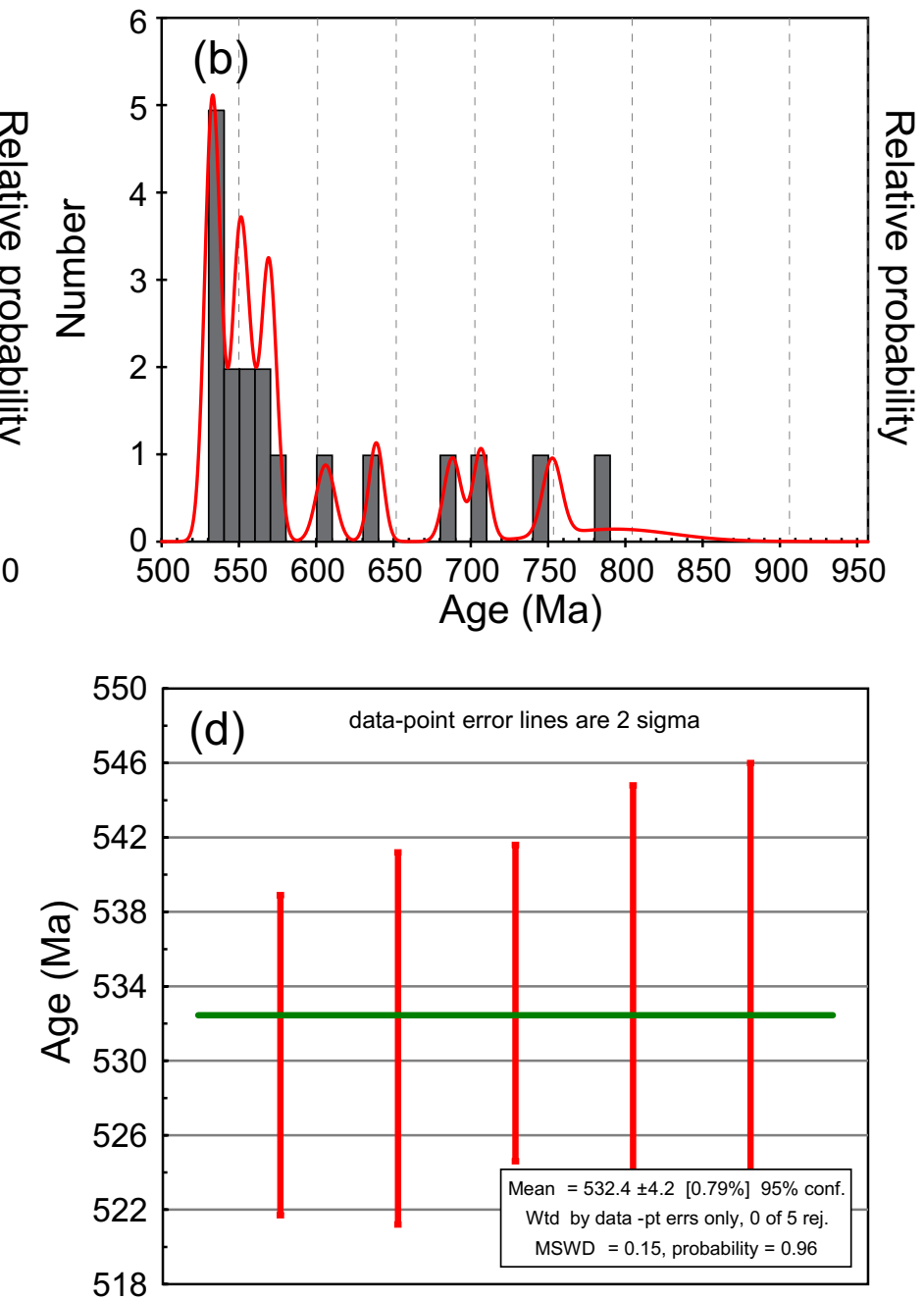

Figure 4. U-Pb zircon diagrams for sample SMB17-235 (data from Table A1). (a) Probability plot for all data between 90 and 102\% concordant. (b) Expanded view of probability plot in (a) for ages less than $950 \mathrm{Ma}$. (c) Concordia diagram for youngest statistically valid age population. (d) Weighted mean diagram for the same 5 grains shown in (c). 

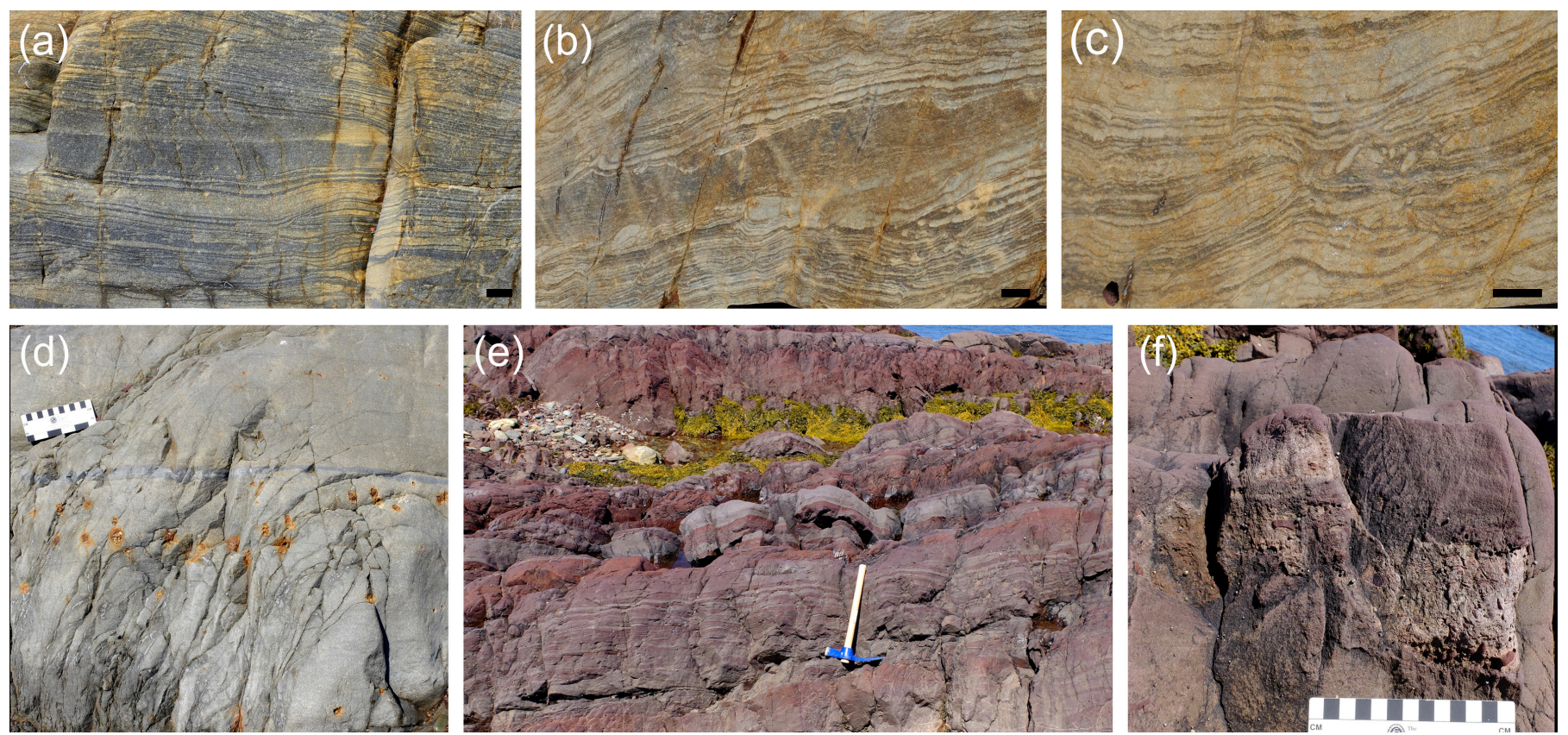

Figure 5. Field images of coastal exposures of the Bengal Road Formation on eastern Scatarie Island. Scale bars represent $10 \mathrm{~mm}$. (a-c) Characteristic lamination and bedding in lower part of measured section of Bengal Road Formation (members 2 and 3). Samples SC17-5 and -6 were collected from fine-grained intervals in this type of rock. Deformed bedding give rise to trace fossil-like structures, particularly well seen in (c). (d) Fine-grained sandstone with large pyrite crystals. (e) Red sandstone and siltstone (member 4). (f) Red nodular limey siltstone (member 4).

microfossils were prepared and examined at Área de Paleontologia, University of Extremadura, Badajoz, following palynological procedures outlined in Vidal (1988). See Appendix B for details on locations and samples. Palynological slides containing figured and representative material are stored with the collections in Nova Scotia Museum of Natural History, Halifax (museum numbers added in the explanation of the figures).

\section{Results: organic-walled microfossils}

All samples from Hay Island had no or only small amounts of dispersed organic material and no identifiable organic-walled microfossils (see Appendix B). Two samples from the Bengal Road Formation yielded poorly preserved organic-walled microfossils (Fig. 6). This material includes probable cyanobacterial filamentous sheaths (Fig. 6a) and organic fragments of uncertain origin. A single poorly preserved acanthomorphic acritarch (Fig. 6b) is identified as Polygonium sp. This acritarch does not provide biostratigraphic information beyond that of a post-Ediacaran age. Sarjeant and Stancliffe (1996) restricted Polygonium to the Cambrian to Devonian interval, but younger occurrences have been reported. These samples provide the first records of organic-walled microfossils from the Bengal Road Formation.

\section{Results-trace fossils}

No definitive trace fossils were observed in the Bengal Road Formation. Bedding-plane exposures are not well developed, which severely limits the possibility of observing any delicate bedding-plane parallel trace fossils. Angular or rod-shaped bodies seen in vertical and oblique section (Figs. $5 b-c)$ have similarity to trace fossils but their interpretation
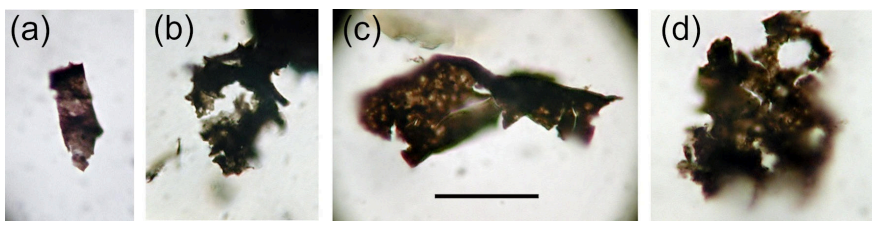

Figure 6. Organic-walled microfossils from Bengal Road Formation, Scatarie Island. Scale bar in $c$ is equivalent to $20 \mu \mathrm{m}$ for a-d. Sample number, the Nova Scotia $\mathrm{Mu}$ seum of Natural History collection number, and England Finder coordinates (for position of microfossils on the palynological slide; https://www.graticulesoptics.com/ products/stage-micrometers-calibration-scales-grids/coordinate-graticules/s7-england-finder) are provided. (a) Possible cyanobacterial filament, SC17-5, NSM020GF14.1, V-51-2. (b) Polygonium sp., SC17-6, NSM020GF14.2, J-431 (c) Organic-walled fragment, SC17-6, NSM020GF14.2, M-41-1. (d) Degraded organic-walled fragment, SC17-6, NSM020GF14.2, B-42-4. 
is complicated by frequent small-scale (syndepositional?) disturbance, fracturing and rotation of laminae and beds. It is probable that structures such as those shown in Fig. 5c represent rotated pieces of primary sedimentary structures.

Trace fossils were observed on several coastal sections on Hay Island (Fig. 2). On the southern part of the island, outcrops of mainly grey-green and dark-grey siltstone contain examples of starved ripples of fine sandstone (Fig. $7 \mathrm{~b}$ ) and teichichnid trace fossils with clear evidence for spreite (Fig. 7a). The spreiten show at least 5 lamellae, with downward-oriented convexity, which indicates a retrusive development of the spreite, although no causative burrow was clearly identified. These trace fossils are assigned to $\mathrm{Te}$ ichichnus isp.

Trace fossils were observed on weathered outcrop of cleaved grey-green siltstone on the northern tip of the island, with the most notable being small, vertically oriented, spiral trace fossils (Figs. 8a-c). These spirals are developed within silty material and filled with fine sand related to thin sandstone event beds. The best exposed specimen (Fig. 8a) has two whorls (whorl height approximately 6 $\mathrm{mm}$ ), a burrow diameter of $0.7 \mathrm{~mm}$ and a spiral radius of $1.6 \mathrm{~mm}$. Another less well-exposed specimen with comparable dimensions shows three whorls of the spiral (Fig. $8 b)$. Both in dimensions and spiral geometry this material is like Gyrolithes scintillus from the Chapel Island Formation, Burin Peninsula, Newfoundland, as described by Laing et al. (2018). Other trace fossils from the Hay Island outcrop consist of short plug-shaped cones (Fig. 8d). Similar trace fossils from the Chapel Island Formation in Newfoundland
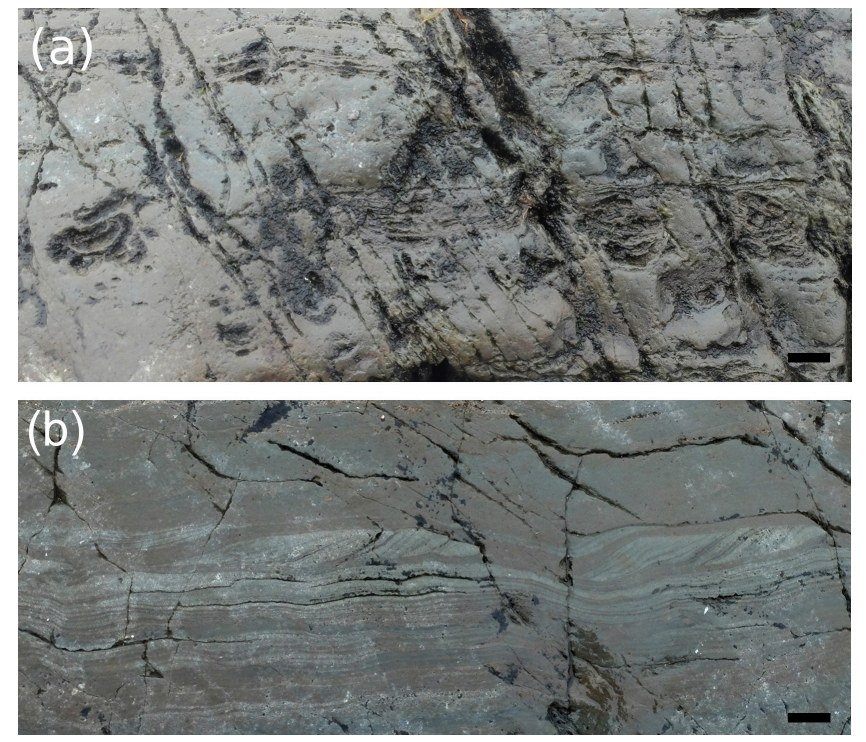

Figure 7. Field images of trace fossils and sedimentary structures in the MacCodrum? Formation, southern Hay Island. (a) Siltstone and fine-grained sandstone with transverse sections through Teichichnus spreiten. Scale bar represents $10 \mathrm{~mm}$. (b) Current ripple cross-lamination, scale bar represents $10 \mathrm{~mm}$. have been identified as Conichnus, but both the material described here and that from Newfoundland could alternatively be the fill of the funnel-shaped top of an otherwise not preserved, short, vertical trace fossil. Additional nondescript trace fossils are also present (Fig. 8e). Trace fossils in this outcrop exhibit "floating" and "adhering" preservation, similar to that commonly seen in the Chapel Island Formation of Newfoundland (Droser et al. 2002), in which sandfilled burrows are floating in a finer-grained matrix (Fig. 8e) or secondarily adhered to a later sand bed. A loose sample along the same stretch of outcrop show Teichichnus isp. and more strongly developed sediment mixing (Fig. 8f). The slab is sedimentologically similar and is interpreted as a less weathered sample from the same interval of the succession.

\section{DISCUSSION}

Both the detrital zircon ages and fossils described here confirm a Cambrian age for the siliciclastic successions on eastern Scatarie Island and on Hay Island, a conclusion previously based on lithological correlation with the Bengal Road and MacCodrum formations, respectively, on Cape Breton Island (Barr et al. 1996). The maximum depositional ages of 532 and $526 \mathrm{Ma}$ and the presence of the acritarch Polygonium sp. from the Bengal Road Formation on eastern Scatarie Island demonstrate that the upper part of this formation is definitely younger than the late Ediacaran Rencontre Formation in Newfoundland, with which the Bengal Road Formation was compared by Landing (1991, 1996). The new data reported here, combined with detrital zircon age constraints from Cape Breton Island (Barr et al. 2012; Willner et al. 2013), indicate that the Bengal Road Formation spans much of the Fortunian and Cambrian Stage 2. The age of the base of the formation is not known, nor is the duration of the inferred break in sedimentation between the Main-à-Dieu and Mira River groups. The stratigraphic position of the Bengal Road Formation could in part be equivalent to that of the Ratcliffe Brook Formation in New Brunswick, as previously suggested by Barr et al. (2012); if so, the base of the formation is intra-Fortunian.

The geological mapping information (Barr et al. 1992, 1996; this paper) indicates that the eastern coast of Scatarie Island and Hay Island are both part of the same east-plunging synclinorium (Fig. 2). Based on lithological characteristics Barr et al. (1996) attributed the Hay Island succession to the MacCodrum Formation, in which case the sandstone facies of the Sgadan Lake Formation either is not exposed above sea level or was never developed in this region. The trace fossils reported here provide ichnostratigraphic evidence for a post-Ediacaran age of the Hay Island succession, especially the presence of Teichichnus. The earliest Teichichnus appear in late Fortunian and Stage 2 rocks, and more generally spreite-burrows have been used as evidence for a post-Ediacaran age in the absence of other evidence (e.g., Bland and Goldring 1995; Jensen et al. 2016). Teichichnus is a common element in lower Cambrian strata of Avalonia 

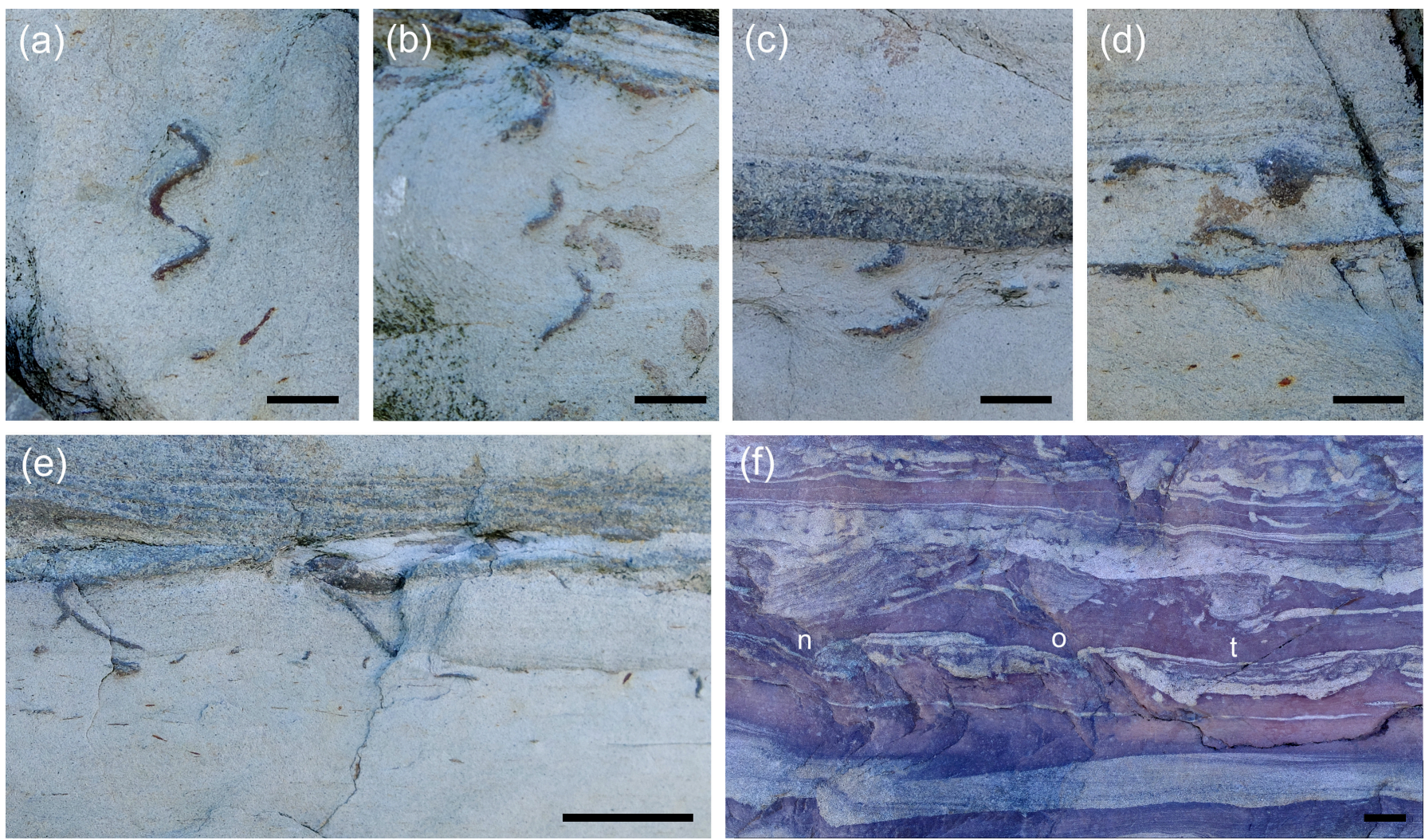

Figure 8. Field images of trace fossils from MacCodrum? Formation, northern Hay Island. (a-e) Images from vertical surfaces of cleaved siltstone. (a-c) Vertical spiral trace fossil Gyrolithes scintillus. Scale bars represent $5 \mathrm{~mm}$. (d) Small plug-shaped sand-filled structure, which may be a Conichnus or a funnel-shaped top of a vertical tube. Scale bar represents $5 \mathrm{~mm}$. (e) Several short trace fossils in "floating" preservation along a bedding plane marked by gentle change in grain size. A larger burrow is a possible Gyrolithes. Scale bar represents $5 \mathrm{~mm}$. (f) Vertical view of alternation of sandstone and mudstone in loose block. Along mid-line three discrete Teichichnus are seen in, from right to left, transverse ( $t$ ), oblique (o), and near-longitudinal (n) section. Scale bar represents $5 \mathrm{~mm}$.

and Baltica (Loughlin and Hillier 2010). In the Chapel Island Formation Teichichnus occurs sparsely in member 2, more commonly so in members 3 and 4, where it is the dominant trace fossil (Landing et al. 1989; Droser et al. 2002; Gougeon et al. 2018). It is also prominent in the Bonavista Group, in which Landing et al. (1989) named a Teichichnus Interval. In the Mira River area Teichichnus is common in red mudstone of the Canoe Brook Formation (Landing 1991). The earliest Gyrolithes straddle the Ediacaran/Cambrian boundary in Newfoundland (Gehling et al. 2001; Laing et al. 2018), and northern Norway (Jensen et al. 2018). Laing et al. (2018) documented Gyrolithes scintillus from close to the basal Cambrian GSSP through $400 \mathrm{~m}$ of section of member 2 of the Chapel Island Formation. If the Hay Island succession overlies that on Scatarie Island, these Gyrolithes scintillus are younger than occurrences in Newfoundland.

Finally it is noted that the maximum depositional ages from zircon in the Bengal Road Formation on Scatarie Island are close to the age for the base of the Canoe Brook Formation on Cape Breton Island as inferred from fossils. This suggests that future work is needed to evaluate possible regional differences between the sedimentary successions on Cape Breton and Scatarie islands. Furthermore, although attribution of the Hay Island succession to the MacCodrum Formation is tentatively maintained here, further studies are needed to confirm this assignment, and to evaluate the possibility that the Hay Island succession is younger than the MacCodrum Formation, and perhaps consistent with the assignment by Barr and White (2017c) to the Miaolingian Trout Brook Formation.

\section{ACKNOWLEDGEMENTS}

We thank Bruce Hatcher and student assistants from Cape Breton University for transportation by Zodiac to Scatarie Island. We are grateful to Brandon Boucher and Chris McFarlane for assisting Deanne van Rooyen with the $\mathrm{U}-\mathrm{Pb}$ dating at the University of New Brunswick and for providing invaluable advice in processing and interpreting the age data. We thank Tim Fedak, Nova Scotia Museum of Natural History, for providing collection numbers. Sören Jensen and Teodoro Palacios acknowledge funding from Ministerio de Economía. Industria y Competitividad grant CGL 2017- 
87631-P. Sandra Barr acknowledges support from Natural Sciences and Engineering Research Council of Canada Discovery Grant RGPIN-2016-04860. We thank journal reviewers Robert MacNaughton and Andrea Mills for their helpful comments which improved the clarity and readability of the manuscript.

\section{REFERENCES}

Andersen, T. 2002. Correction of common lead in $\mathrm{U}-\mathrm{Pb}$ analyses that do not report $204 \mathrm{~Pb}$. Chemical Geology, 192, pp.59-79. https://doi.org/10.1016/S00092541(02)00195-X

Archibald, D.B., Barr, S.M., Murphy, J.B., White, C.E., MacHattie, T.G., Escarraga, E.A., Hamilton, M.A., and McFarlane, C.R.M. 2013. Field relationships, petrology, age, and tectonic setting of the Ordovician West Barneys River Plutonic Suite, southern Antigonish Highlands, Nova Scotia, Canada. Canadian Journal of Earth Sciences, 50, pp. 727-745. https://doi.org/10.1139/cjes-20120158

Barr, S.M. and Raeside, R.P. 1989. Tectono-stratigraphic terranes in Cape Breton Island, Nova Scotia: implications for the configuration of the northern Appalachian orogen. Geology, 17, pp. 822-825. https://doi. org/10.1130/0091-7613(1989)017<0822:TSTICB $>2.3$. $\mathrm{CO} ; 2$

Barr, S.M. and White, C.E. 1989. The Main-à-Dieu sequence: an extensive late Precambrian volcanic-sedimentary package in southeastern Cape Breton Island. Nova Scotia Department of Mines and Energy, Report 89-3, pp. 149-152.

Barr, S.M. and White, C. E. 2017a. Overview map showing locations of bedrock geology maps for Cape Breton Island, Nova Scotia. Nova Scotia Department of Natural Resources, Geoscience and Mines Branch, Open File Map ME 2017-006, scale 1:220 000.

Barr, S. M. and White, C. E. 2017b. Bedrock geology legend for Cape Breton Island, Nova Scotia; Nova Scotia Department of Natural Resources, Geoscience and Mines Branch, Open File Illustration ME 2017-001.

Barr, S. M. and White, C. E. 2017c. Bedrock geology map of Glace Bay Area, NTS 11J/04, Cape Breton County, Nova Scotia, Nova Scotia Department of Natural Resources, Geoscience and Mines Branch, Open File Map ME 2017021, scale 1:50.000.

Barr, S.M., White, C.E., and Macdonald, A.S. 1992. Revision of upper Precambrian-Cambrian stratigraphy southeastern Cape Breton Island, Nova Scotia; in Current Research, Part D; Geological Survey of Canada, Paper 92-1 D, pp. 21-26. https://doi.org/10.4095/132875

Barr, S.M., White, C.E., and Macdonald, A.S. 1996. Stratigraphy, tectonic setting, and geologic history of Late Precambrian volcanic-sedimentary-plutonic belts in southeastern Cape Breton Island, Nova Scotia. Geological Survey of Canada Bulletin 468, 84 p. https://doi.

\section{org $/ 10.4095 / 208235$}

Barr, S.M., Davis, D.W., Kamo, S., and White, C.E. 2003. Significance of $\mathrm{U}-\mathrm{Pb}$ ages of detrital zircon in quartzite from peri-Gondwanan terranes, New Brunswick and Nova Scotia, Canada. Precambrian Research, 126, pp. 123-145. https://doi.org/10.1016/S0301-9268(03)00192-X

Barr, S.M., Hamilton, M.A., Samson, S.D., Satkoski, A., and White, C.E. 2012. Provenance variations in northern Appalachian Avalonia based on detrital zircon age patterns in Ediacaran and Cambrian sedimentary rocks, New Brunswick and Nova Scotia, Canada. Canadian Journal of Earth Sciences, 49, pp. 533-546. https://doi.org/10.1139/ e11-070

Bevier, M.L., Barr, S.M., White, C.E., and Macdonald, A.S. 1993. U-Pb geochronologic constraints on the volcanic evolution of the Mira (Avalon) terrane, southeastern Cape Breton Island, Nova Scotia. Canadian Journal of Earth Sciences, 30, pp. 1-10. https://doi.org/10.1139/e93$\underline{001}$

Bland, B.H. and Goldring, R. 1995. Teichichnus Seilacher 1955 and other trace fossils (Cambrian?) from the Charnian of central England. Neues Jahrbuch für Geologie und Paläontologie, Abhandlungen, 195, pp. 5-23. https:// doi.org/10.1127/njgpa/195/1995/5

Dickinson, W.R. and Gehrels, G.E. 2010. Insights into North American paleogeography and paleotectonics from $\mathrm{U}-\mathrm{Pb}$ ages of detrital zircons in Mesozoic strata of the Colorado Plateau, USA. International Journal of Earth Sciences, 99, pp. 1247-1265. https://doi.org/10.1007/s00531009-0462-0

Droser, M.L., Jensen, S., Gehling, J.G., Myrow, P.M., and Narbonne, G.M. 2002. Lowermost Cambrian ichnofabrics from the Chapel Island Formation, Newfoundland: implications for Cambrian substrates. Palaios, 17, pp. 3-15. https://doi.org/10.1669/0883-1351(2002)017<0003:LCIFTC $>2.0 . \mathrm{CO} ; 2$

Fletcher, H. 1879. Report of explorations and surveys in Cape Breton, Nova Scotia. Geological Survey of Canada Report of Progress for 1877-78, Part F, 11, 32 p.

Gehling, J.G., Jensen, S. Droser, M.L., Myrow, P.M., and Narbonne, G.M. 2001. Burrowing below the basal Cambrian GSSP, Fortune Head, Newfoundland. Geological Magazine, 138, pp. 213-218. https://doi.org/10.1017/ S001675680100509X

Geyer, G. 2019. A comprehensive Cambrian correlation chart. Episodes, 42, pp. 321-332.https://doi.org/10.18814/ epiiugs/2019/019026

Gougeon, R.C., Mangano, M.G., Buatois, L.A., Narbonne, G.M., and Laing, B.A. 2018. Early Cambrian origin of the shelf sediment mixed layer. Nature Communications, 9(1909), 8 p. https://doi.org/10.1038/s41467-018-04311-8

Hayes, A.O., Bell, W.A., and Goranson, E.A. 1938. Glace Bay sheet; Department of Mines and Resources, Map 362A, scale 1:63 360 .

Hibbard, J.P., van Staal, C.R., Rankin, D.W., and Williams, H., 2006. Lithotectonic map of the Appalachian Orogen, Canada-United States of America; Geological Survey 
of Canada, Map 2096A, scale 1:1 500 000. https://doi. org/10.4095/221912

Hutchinson, R.D. 1952. The stratigraphy and trilobite faunas of the Cambrian sedimentary rocks of Cape Breton Island, Nova Scotia; Geological Survey of Canada, Memoir 263, 124 p. https://doi.org/10.4095/101599

Jensen, S., Harper, D.A.T., and Stouge, S. 2016. Trace fossils from the lower Cambrian Kløftelv Formation, Ella $\varnothing$, North-East Greenland. GFF, 138, pp. 369-376. https:// doi.org/10.1080/11035897.2015.1076029

Jensen, S., Högström, A.E.S., Almond, J., Taylor, W.L., Meinhold, G., Høyberget, M., Ebbestad, J.O.R., Agić, H., and Palacios, T. 2018. Scratch circles from the Ediacaran and Cambrian of Arctic Norway and southern Africa, with a review of scratch circle occurrences. Bulletin of Geosciences, 93, pp. 287-304. https://doi.org/10.3140/bull.geosci. 1685

Laing, B.A., Buatois, L.A., Mángano, M.G., Narbonne, G.M., and Gougeon, R.C. 2018. Gyrolithes from the Ediacaran-Cambrian boundary section in Fortune Head, Newfoundland, Canada: exploring the onset of complex burrowing: Palaeogeography, Palaeoclimatology, Palaeoecology, 405, pp. 171-185. https://doi.org/10.1016/j.palaeo.2018.01.010

Landing, E. 1991. Upper Precambrian through Lower Cambrian of Cape Breton Island: faunas, paleoenvironments, and stratigraphic revision; Journal of Paleontology, 65, pp. 570-595. https://doi.org/10.1017/S0022336000030675

Landing, E. 1996. Avalon: insular continent in the Cambrian. In Avalonian and related peri-Gondwanan terranes of the circum-North Atlantic. Edited by D. Nance and M.D. Thompson. Geological Society America Special Paper, 304, pp. 29-63. https://doi.org/10.1130/0-8137-2304-3.29 Landing, E. 2004. Precambrian-Cambrian boundary interval deposition and the marginal platform of the Avalon microcontinent. Journal of Geodynamics, 37, pp. 411-435. https://doi.org/10.1016/j.jog.2004.02.014

Landing, E., Myrow, P.M., Benus, A.P., and Narbonne, G.M. 1989. The Placentian Series: appearance of the oldest skeletalized faunas in southeastern Newfoundland. Journal of Paleontology, 63, pp. 739-769. https://doi.org/10.1017/ S0022336000036465

Loughlin, N.J.D. and Hillier, R.D. 2010. Early Cambrian Teichichnus-dominated ichnofabrics and palaeoenvironmental analysis of the Caerfai Group, southwest Wales, UK. Palaeogeography, Palaeoclimatology, Palaeoecology, 297, 239-251. https://doi.org/10.1016/j.palaeo.2010.07.030

Ludwig, K.R. 2012. Isoplot 4.15: A geochronological toolkit for Microsoft Excel. Berkeley Geochronological Center. URL <http://www.bgc.org/isoplot etc/isoplot/Isoplot4 15files.zip>, March 2020.

McFarlane, C.R.M. and Luo, Y. 2012. Modern analytical facilities: U-Pb geochronology using $193 \mathrm{~nm}$ Excimer LAICP-MS optimized for in-situ accessory mineral dating in thin sections. Geoscience Canada, 39(3), pp. 158-172.

Palacios, T., Jensen, S., Barr, S.M., and White, C.E. 2009.
Acritarchs from the MacLean Brook Formation, southeastern Cape Breton Island, Nova Scotia, Canada: new data on Middle Cambrian-Lower Furongian acritarch zonation. Palaeogeography, Palaeoclimatology, Palaeoecology, 273, pp. 123-141. https://doi.org/10.1016/j.palaeo.2008.12.006

Palacios, T., Jensen, S., Barr, S.M., and White, C.E. 2015. Stratigraphic constraints on Cambrian stratigraphy. Mira and Bras d'Or terranes, Cape Breton Island, Nova Scotia, Canada. Atlantic Geology, 51, pp. 127-128. https://doi. org/10.4138/atlgeol.2015.005

Paton, C., Hellstrom, J., Paul, B., Woodhead, J., and Hergt, J.M. 2011. Iolite: freeware for the visualisation and processing of mass spectrometric data. Journal of Analytical Atomic Spectrometry, 26, pp. 2508-2518. https://doi. org $/ 10.1039 / \mathrm{clja10172b}$

Petrus, J.A. and Kamber, B.S. 2012. VizualAge: A novel approach to laser ablation ICP-MS U- Pb geochronology data reduction. Geostandards and Geoanalytical Research, 36, pp. 247-270. https://doi.org/10.1111/ j.1751-908X.2012.00158.x

Reynolds, P.H., Barr, S.M., and White, C.E. 2009. Provenance of detrital muscovite in Cambrian Avalonia of Maritime Canada: ${ }^{40} \mathrm{Ar} /{ }^{39} \mathrm{Ar}$ ages and chemical compositions. Canadian Journal of Earth Sciences, 46, pp. 169180. https://doi.org/10.1139/E09-013

Sarjeant, W.A.S. and Stancliffe, R.P.W. 1996. The acritarch genus Polygonium Vavrdová emend Sarjeant and Stancliffe 1994: a reassessment of its constituent species. Annales de la Société géologique de Belgique, 117, pp. 355369. https://doi.org/10.2307/1485867

van Staal, C.R., Barr, S.M., McCausland, P.M., Thompson, M.D., and White, C.E. 2020. Tonian-Ediacaran tectonomagmatic evolution of West Avalonia and its Ediacaran-Early Cambrian interactions with Ganderia: an example of complex terrane transfer due to arc-arc collision? In Pannotia to Pangaea: Neoproterozoic and Paleozoic orogenic cycles in the circum-Atlantic region. Edited by J.B. Murphy, R.A. Strachan, and C. Quesada. Geological Society, London, Special Publications, 503. https://doi. org/10.1144/SP503-2020-23

Vidal, G. 1988. A palynological preparation method. Palynology, 12, pp. 215-220. https://doi.org/10.1080/019161 22.1988.9989345

Weeks, F.J. 1954. Southeast Cape Breton Island, Nova Scotia. Geological Survey of Canada, Memoir 277, 112 p. https:// doi.org/10.4095/101500

Willner, A.P., Barr, S.M., Gerdes, A., Massonne, H.-J., and White, C.E. 2013. Origin and evolution of Avalonia: evidence from $\mathrm{U}-\mathrm{Pb}$ and $\mathrm{Lu}-\mathrm{Hf}$ isotopes in zircon from the Mira terrane, Canada, and the Stavelot-Venn Massif, Belgium. Journal of the Geological Society, London, 170, pp. 769-784. https://doi.org/10.1144/jgs2012-152

Editorial responsibility: Robert A. Fensome 


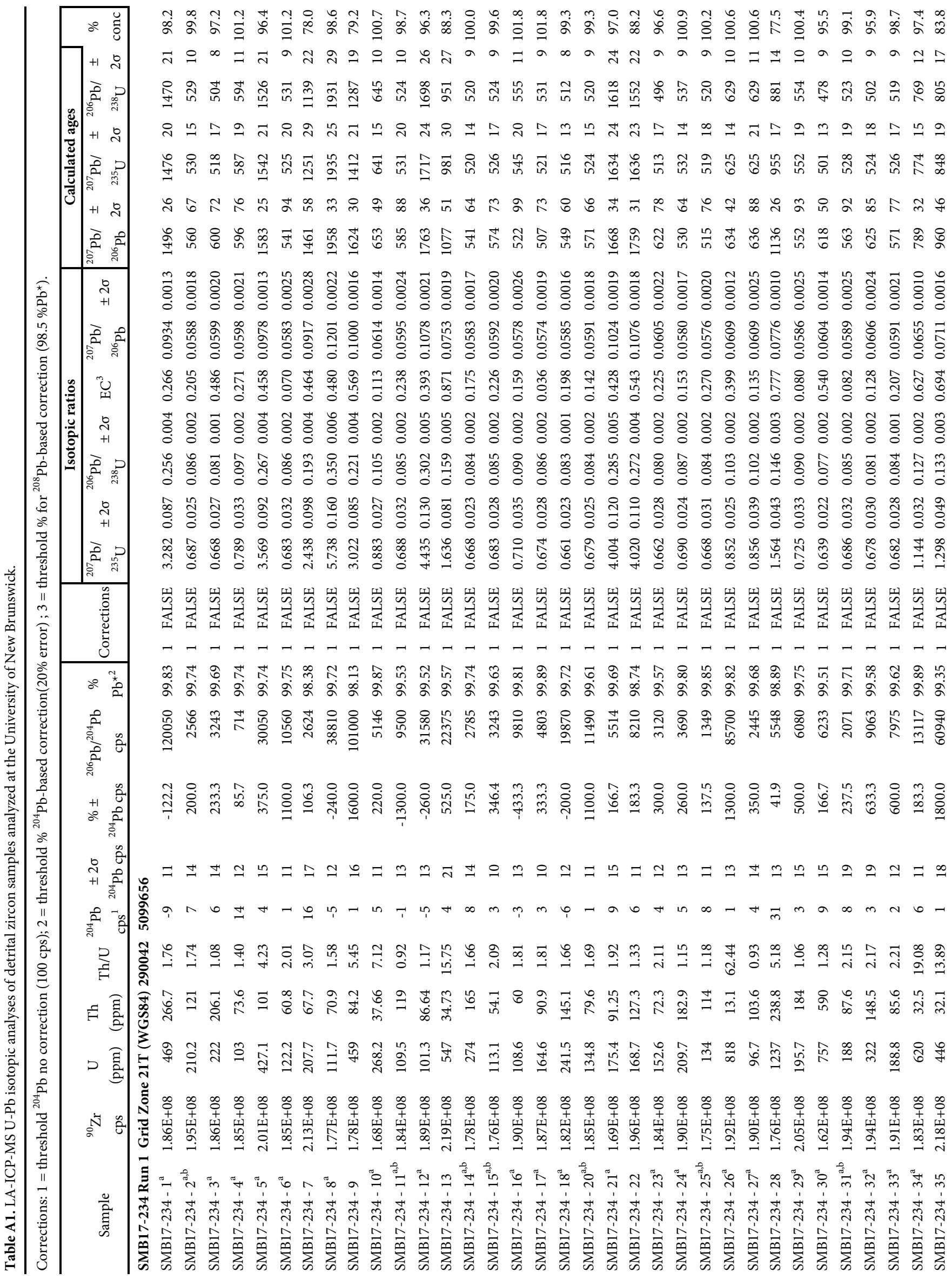




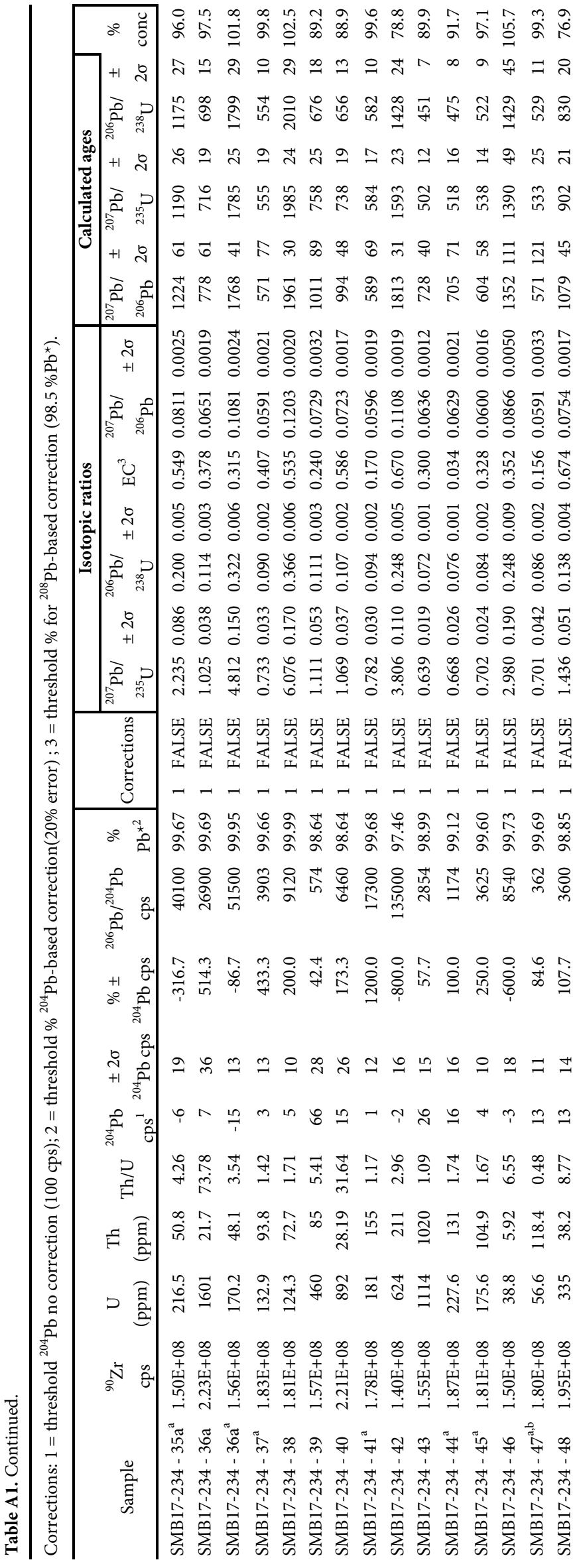

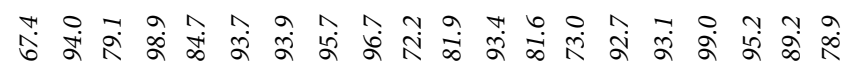

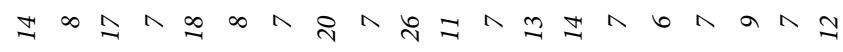

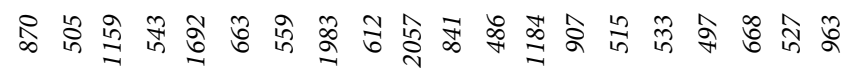

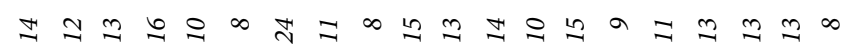

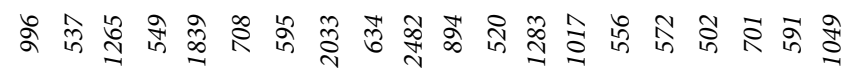

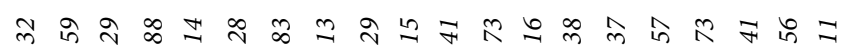
ปิ่ ఫ艹

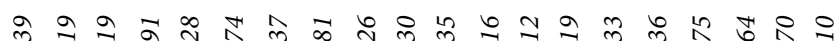

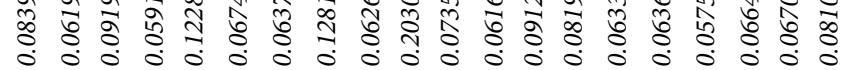
సิ สิ

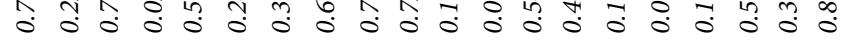

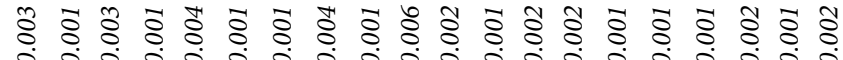
\#

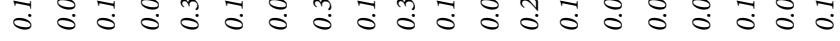

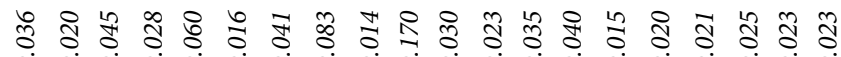

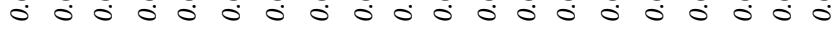

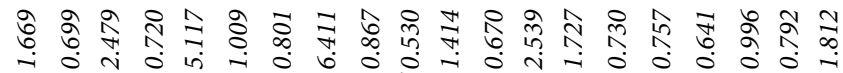

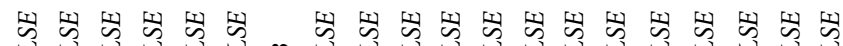

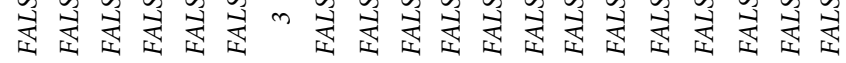

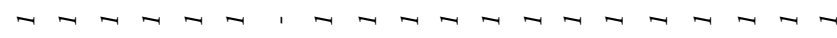
ชิ

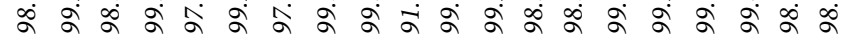

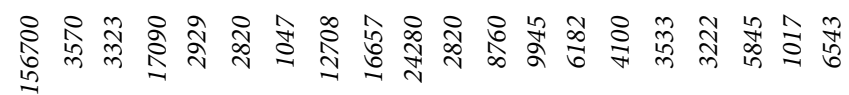

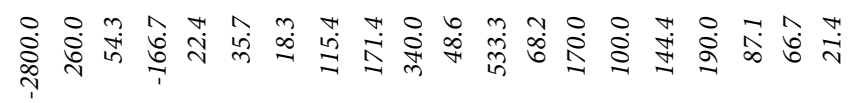

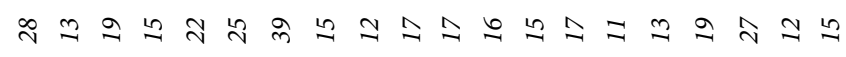

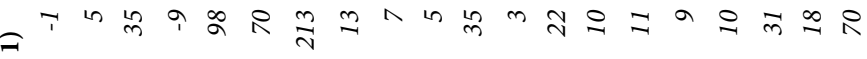

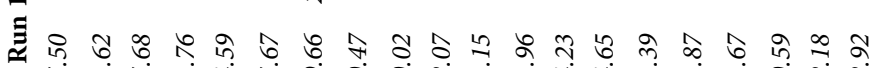

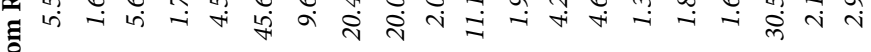

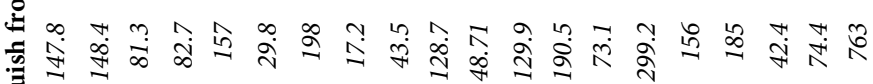

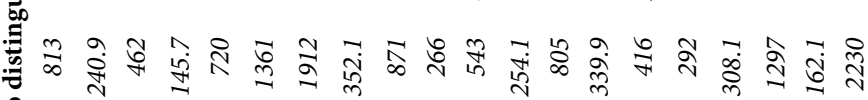
8 幽 $\infty$

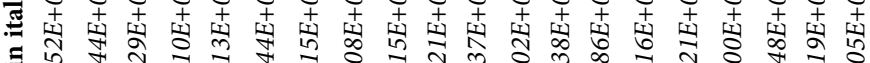

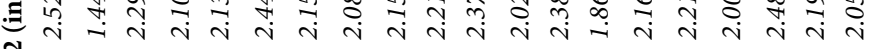

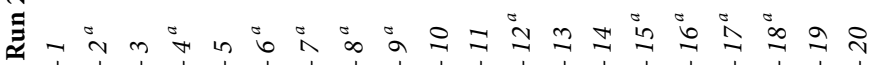

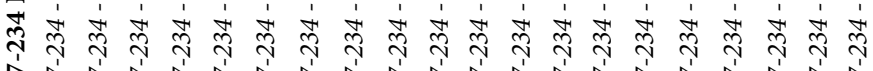

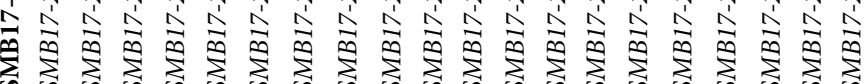




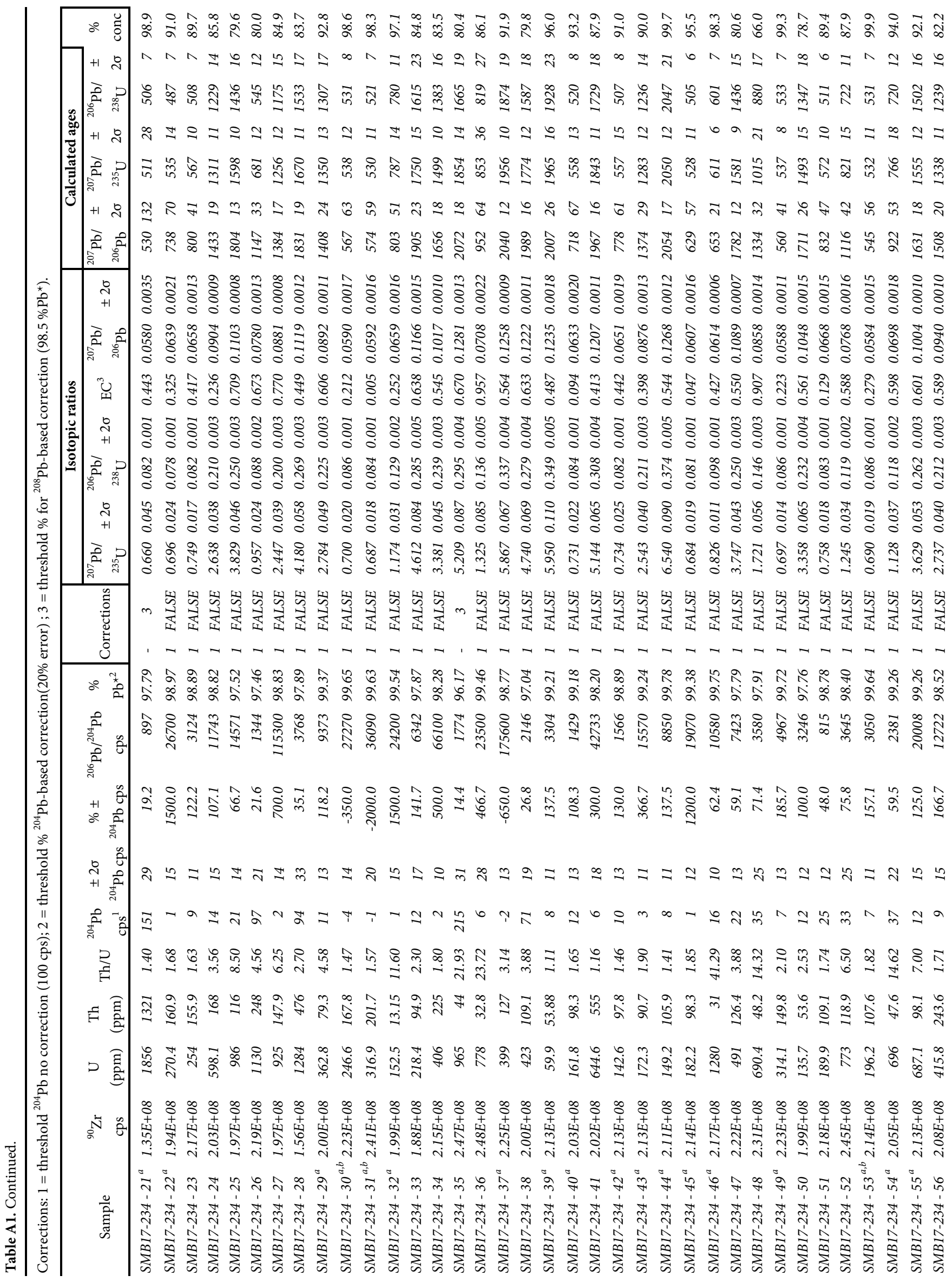




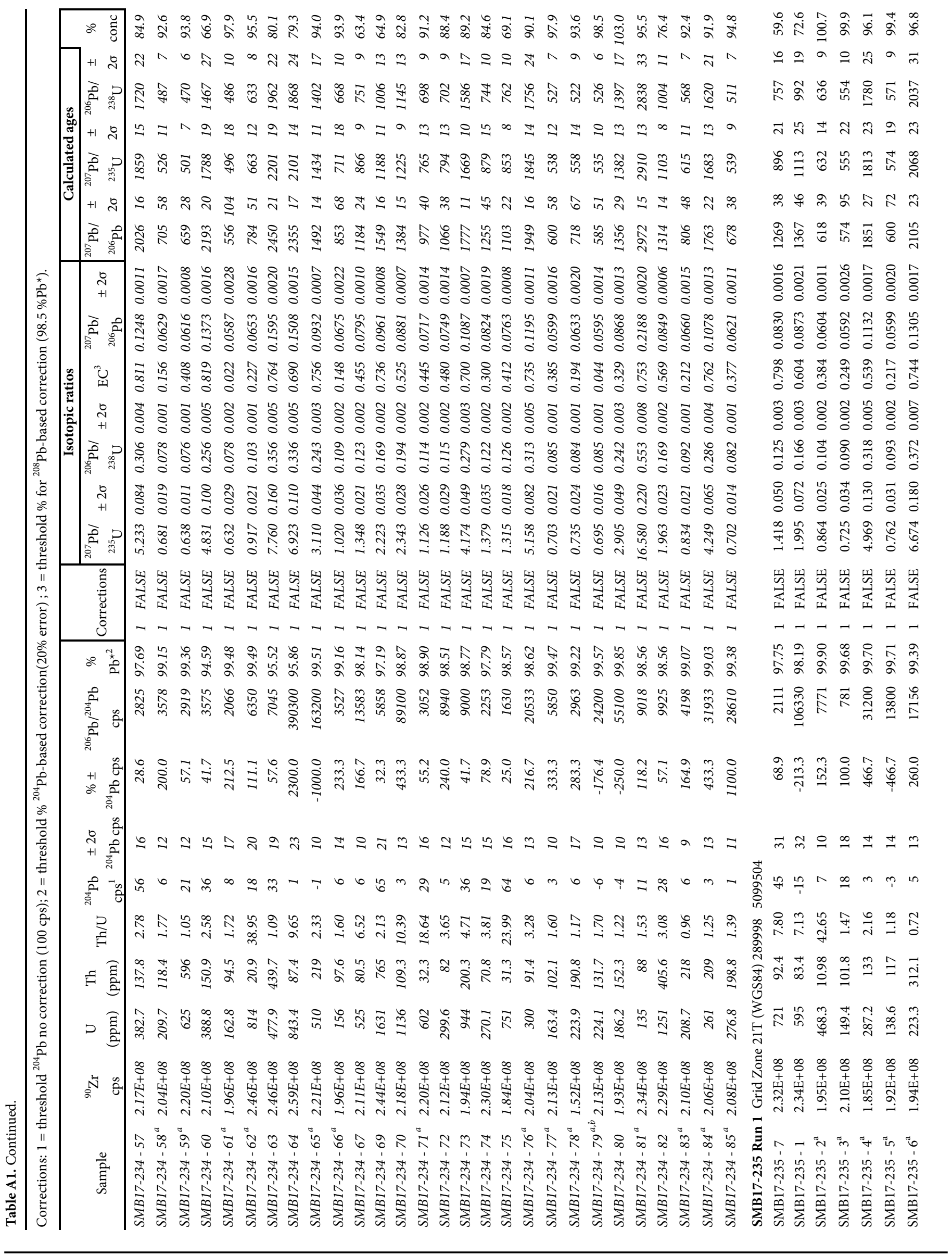




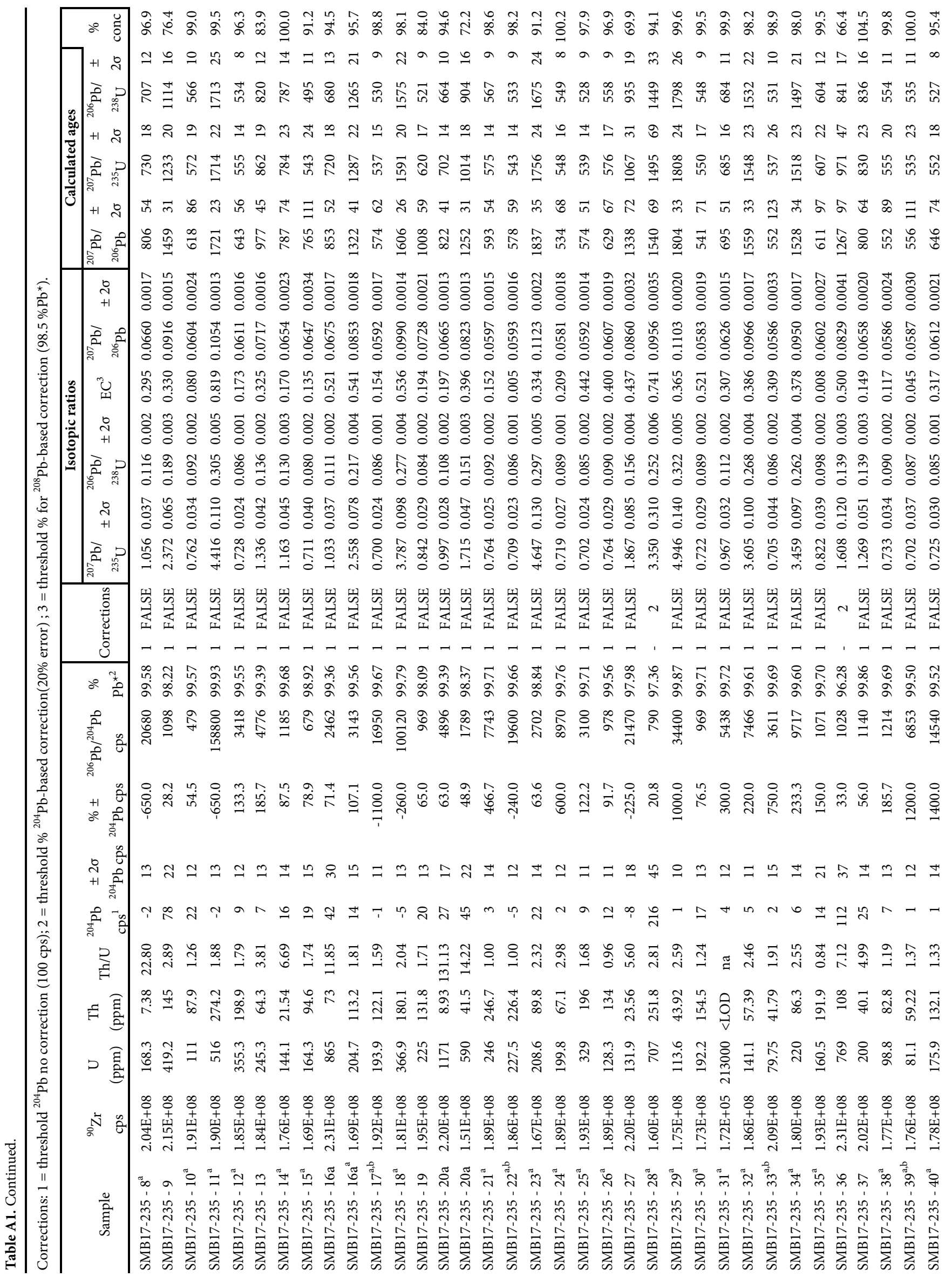




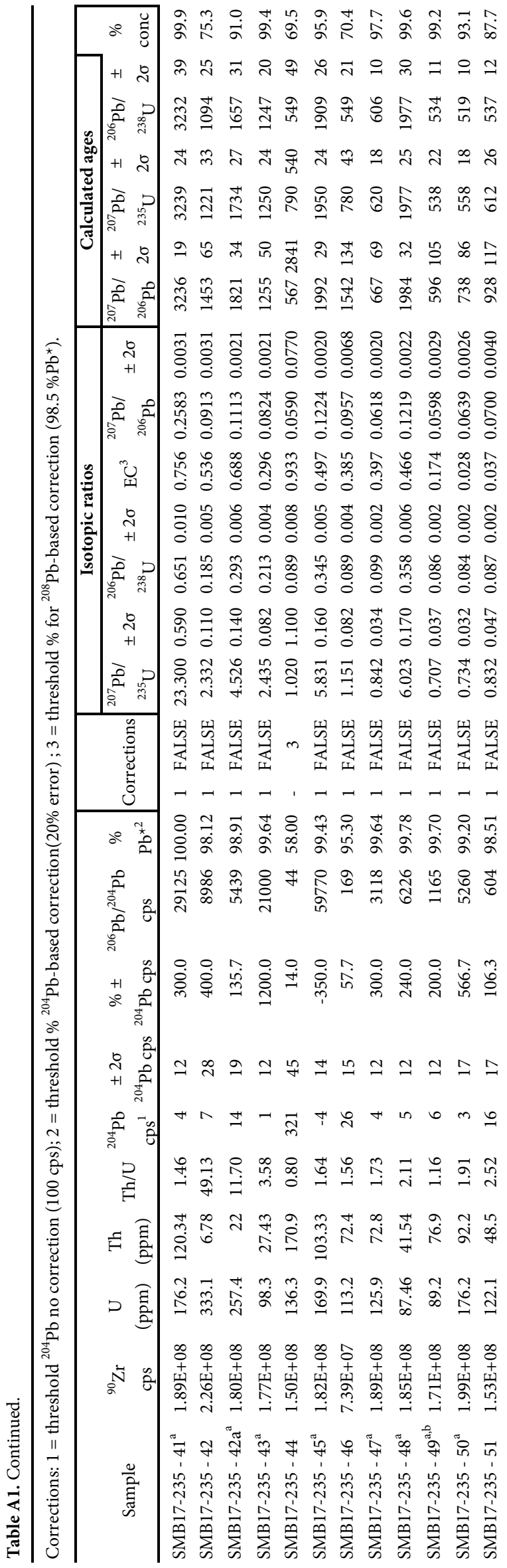

ڤं

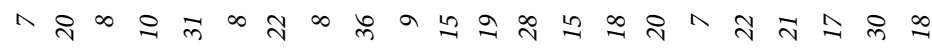
윙족융 \&

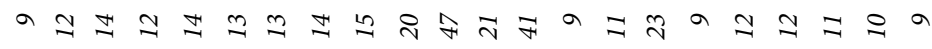

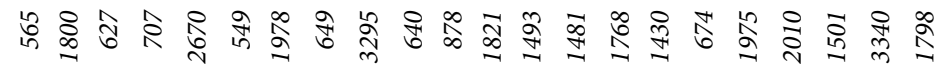

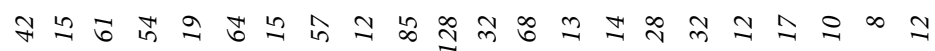

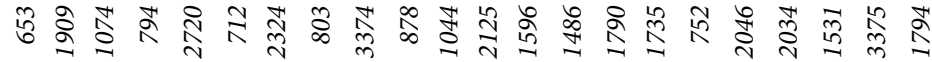

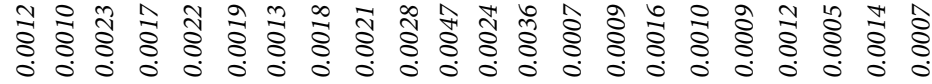

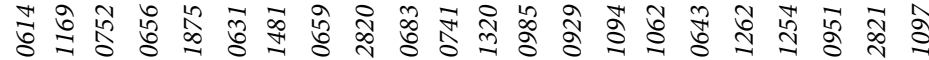

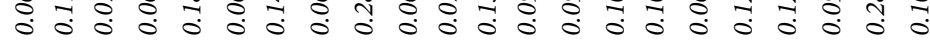

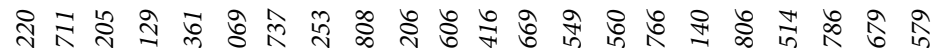

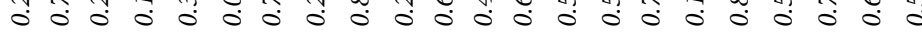

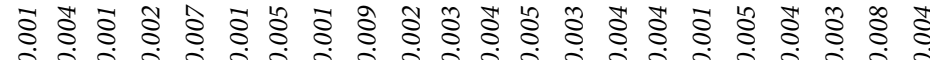

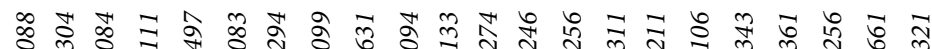

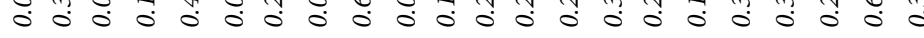

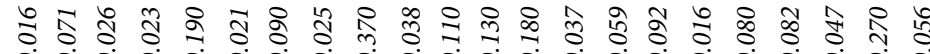

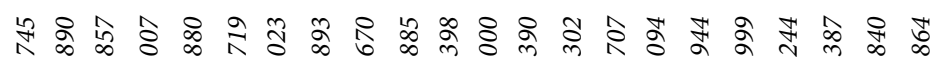

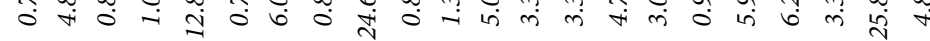

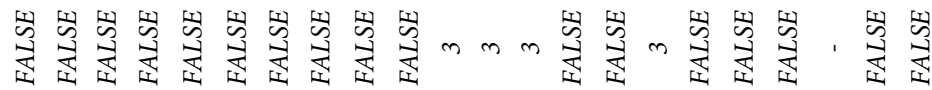

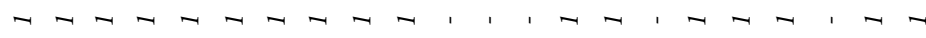
约

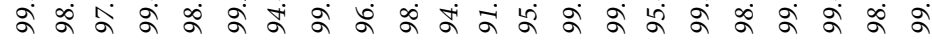

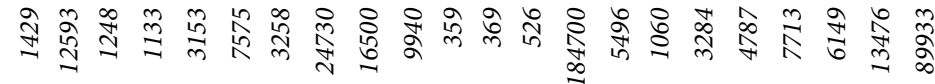

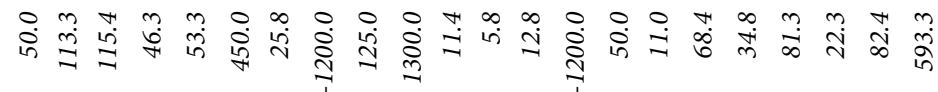

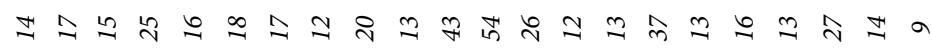

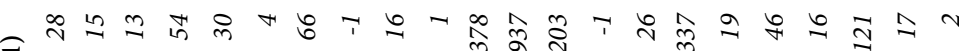

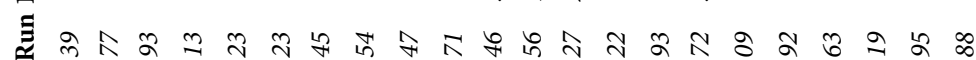
च

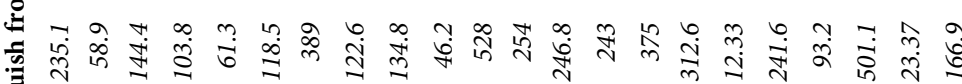

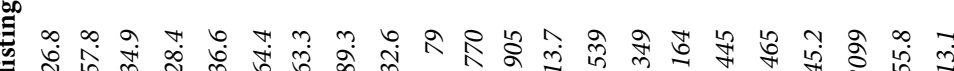

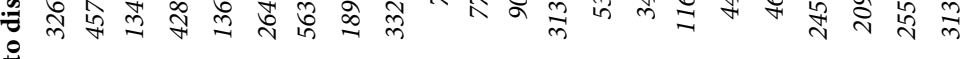
象

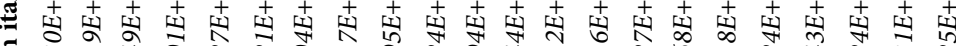

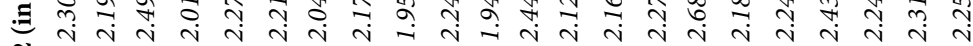

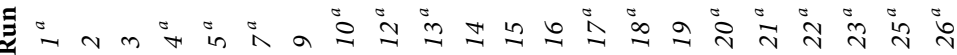

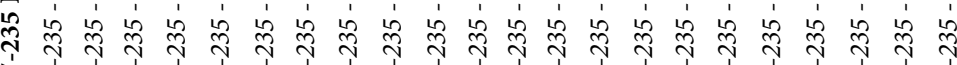

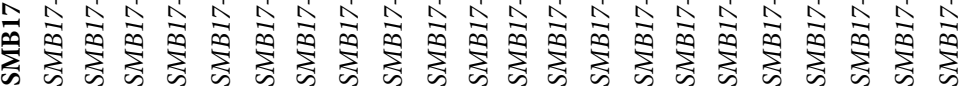




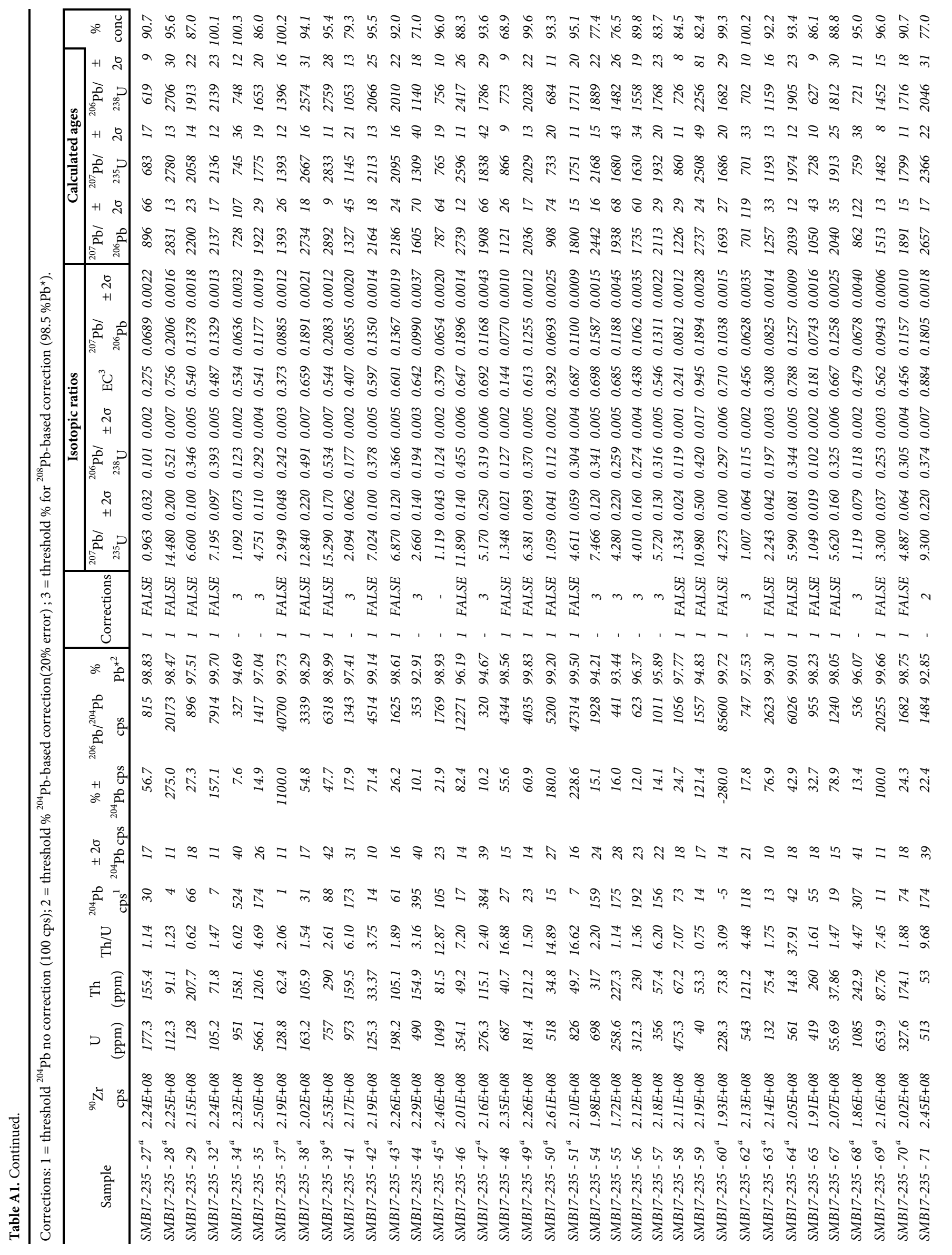




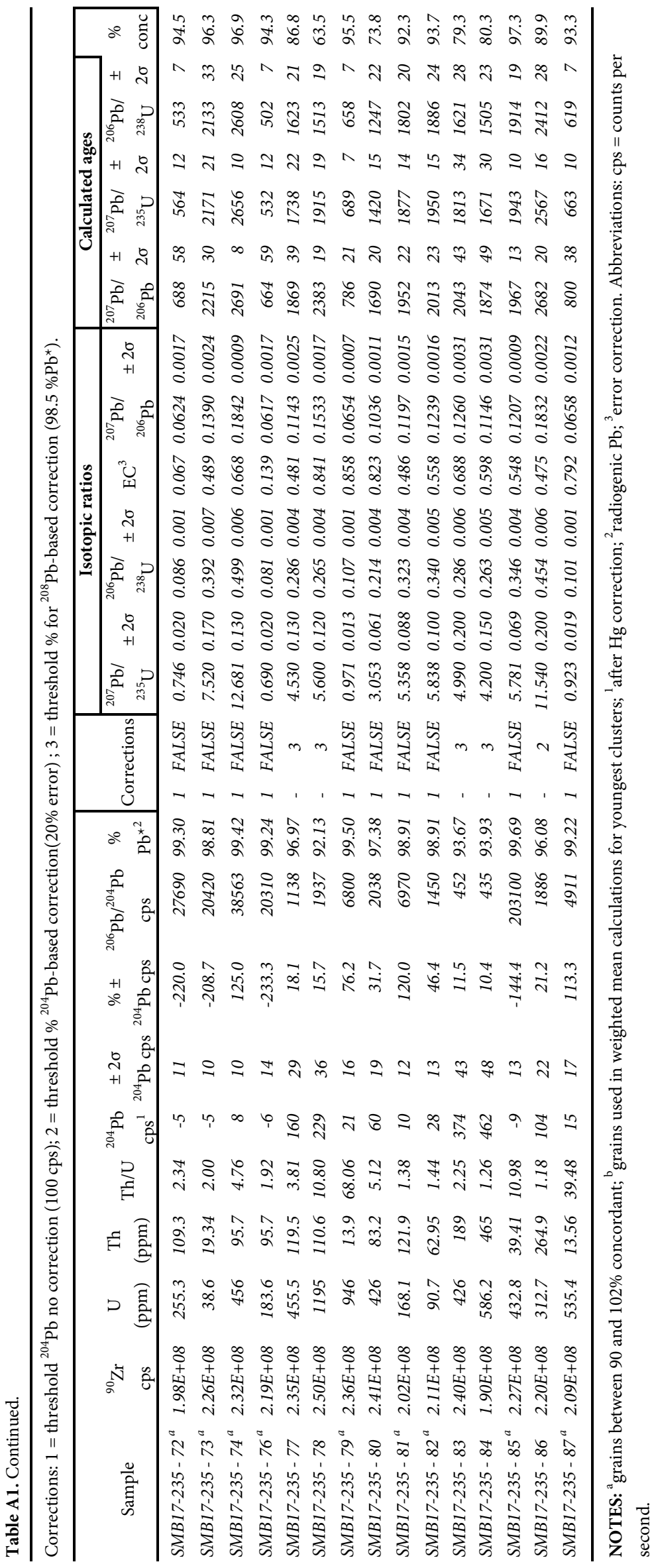




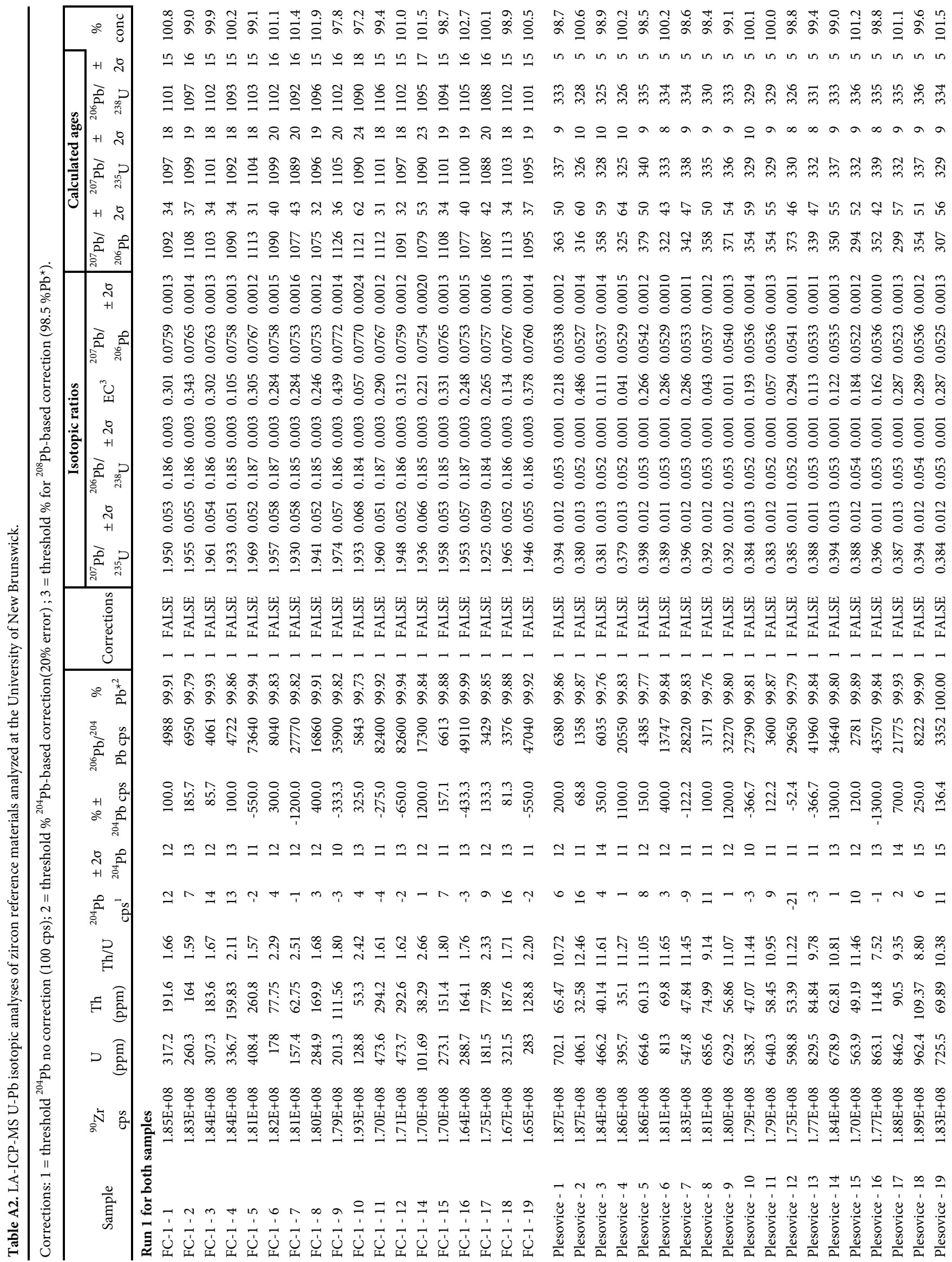




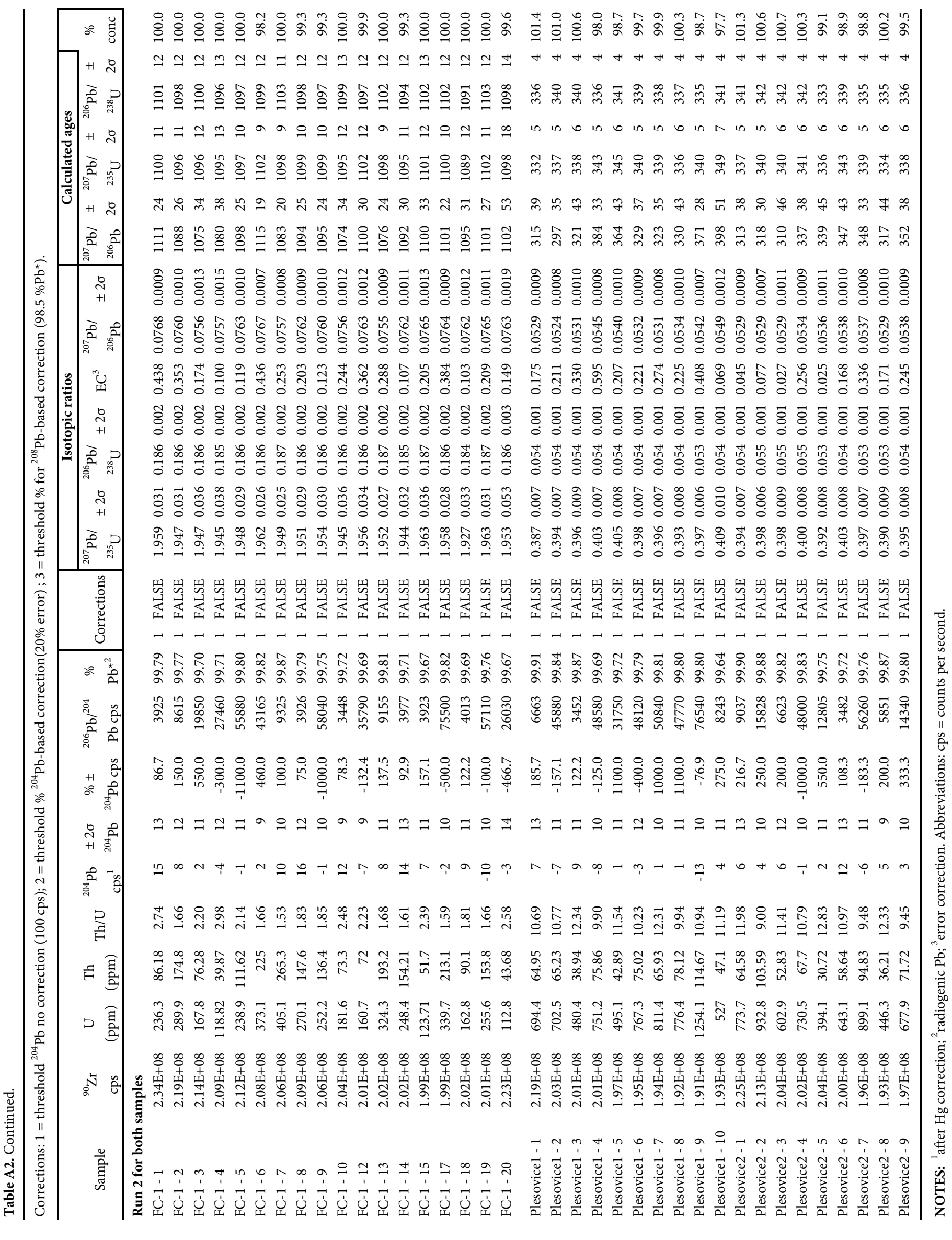




\section{APPENDIX B}

Location and sample information, organic-walled microfossils and trace fossils. Sample coordinates are in Grid Zone $21 \mathrm{~T}$ (WGS84). Locations are indicated also on Figure 2 and shown in a stratigraphic column (Fig. B1).

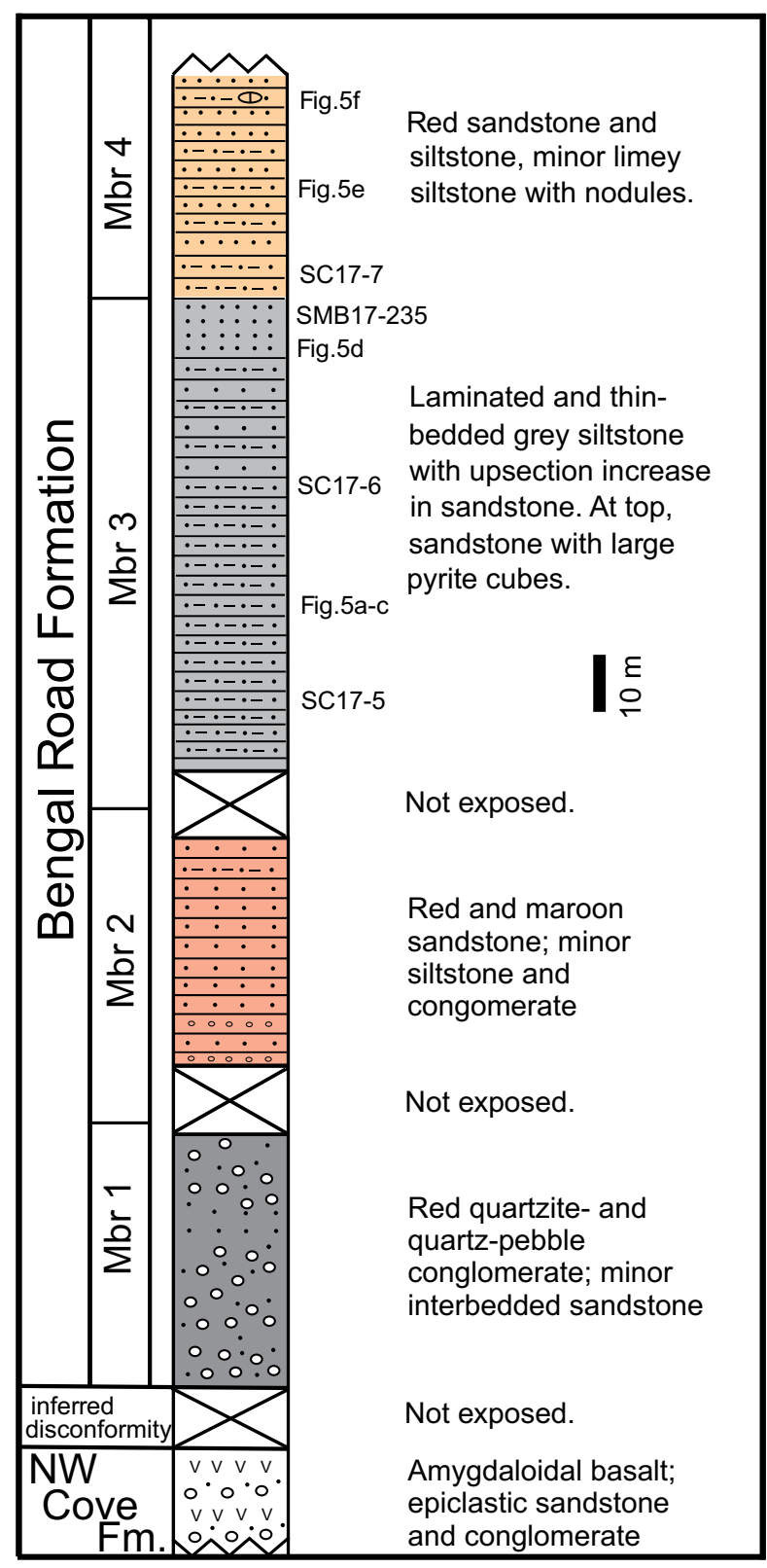

Figure B1. Stratigraphic interpretation of the southern limb of the southernmost syncline on the eastern shore of Scatarie Island (Fig. 2). Members 3 and 4 were logged in August 2017. Members 1 and 2 are schematic and based on notes made in 1991 when they were partially exposed. Abbreviation: NW Cove Fm = Northwest Cove Formation .
Scatarie Island, Bengal Road Fm. Coastal section of upper part of Bengal Road Formation

SC17-5. 0289970, 5099472. Abundant dispersed organic matter and very scarce organic-walled microfossils that are limited to fragments without recognizable forms, except for a small filament of possible cyanobacteria (Fig. 6a).

SC17-6. 0289994, 5099484. Small amount of dispersed organic matter and very scarce organic-walled microfossils without recognizable forms, except for an acritarch assigned to Polygonium sp. (Fig. 6b).

SC17-7. 0289995, 5099517. Small amount of dispersed organic matter. Possible black carbonaceous fragments without recognizable forms.

\section{Hay Island, MacCodrum? Formation}

1. Section on southern Hay Island at 0291878, 5099931. Teichichnid trace fossils (Fig. 7). Sample SC17-2, with small amount of dispersed organic matter, possible black carbonaceous fragments without recognizable morphologies. From same area at 0291885, 5099911, sample SC17-3, with small amount of dispersed organic matter, possible black carbonaceous fragments without recognizable morphologies. Among the maceration-resistant minerals are some idiomorphic zircon crystals. Also sample SC17-4, with no dispersed organic matter. Possible black carbonaceous fragments without recognizable shapes.

2. Section on northeastern Hay Island at 0292071, 5100170 , cleaved dark grey siltstone with carbonate nodules. Sample SC17-8, with small amounts of organic matter. Possible black carbonaceous fragments without recognizable forms.

3. Section on northern Hay Island at 0292230, 5100309. Gyrolithes, Teichichnus and other trace fossils (Fig. 8). Sample SC17-9, with no dispersed organic material. Possible black carbon fragments without recognizable forms. 